\title{
Beyond Faith and Reason: Epistemic Justification in Earliest Christianity
}

\author{
Juraj Franek \\ (Masaryk University, Brno)
}

\begin{abstract}
Much of the scholarly discussion pertaining to epistemological assumptions regarding the earliest Christian authors has been framed by a series of dichotomies, placing "faith" and "religion" on one side and "reason" and "philosophy" on the other. I argue in this paper that uncritical use of these hard-to-define and overly general concepts as blanket categories to analyse Christian writings from the first three centuries CE inevitably causes major methodological issues and could be seen as heuristically unjustified. I suggest that a more frugal approach may be initiated by reconceptualizing the traditional "faith" vs. "reason" dichotomy in terms of the concept of personal and impersonal epistemic justification.
\end{abstract}

\section{Keywords}

Early Christian literature; faith and reason; epistemic justification; apologetics; miracles; morality; divine inspiration

Even a brief glimpse at this paper's list of references makes it clear that framing the epistemological problems of the earliest Christian authors in terms of "faith" vs. "reason" or "philosophy" is commonplace among scholars. ${ }^{1}$ Venerable as this tradition is, echoing Paul's introduction of this dichotomy in 1 Corinthians (discussed below), its value as a heuristic tool is doubtful, mainly due to the extreme polysemy of all of the central notions involved. Its uncritical use often leads to contradictory assessments of the main protagonists of early Christian literature. For instance, there are modern scholars who argue that "Paul initiated a negative response to philosophy, especially to the rigour of rational thought"; ${ }^{2}$ for others, he worked "precariously on the treacherous edges of the realm of logicality, and the spirituality required in the recipient of the Pauline message is not a decoding agent that simply bypasses the hazards which lie in the way of reason" (whatever this obscure phrase might mean). ${ }^{3}$ There are those who claim

1 For a convenient anthology of relevant texts pertaining to the "faith" vs. "reason" dichotomy, see Helm (1999).

2 Freeman (2009: p. 176).

3 Moores (1995: p. 160). 
that the introductory chapters of Justin Martyr's Dialogue with Trypho betray an "antiphilosophical character"; ${ }^{4}$ others suggest that, in Justin's work in general, "every nerve is strained to demonstrate that, on assumptions every educated person would share, Christianity is reasonable and wholly tenable by the philosophically minded". ${ }^{5}$ With respect to the famous lines of Tertullian's On the Flesh of Christ, ${ }^{6}$ the Latin apologist is proclaimed to be "thoroughly rationalistic"; his paradox considered a "manifesto on behalf of reason in religious faith", ${ }^{7}$ even the "exigency of reason". ${ }^{8}$ For other scholars, Tertullian's notion of faith displays "totalitarian requirements" and constitutes a "pure position", entailing decisive rejection of any unrevealed wisdom, ${ }^{9}$ with his paradoxes a testimony to the fact that "Christian revelation offended common sense and conventional philosophy". ${ }^{10}$

As mentioned above, I suspect that the irreconcilable interpretations of the central protagonists of early Christianity are due in part to ambiguous use of such complex general notions as "faith", "reason", and "philosophy", which leads me to propose an alternative methodological approach. In this paper, I will analyse early Christian discourse related to the defence of faith using the concept of epistemic justification. Epistemic justification has been at times defined very broadly as "that which makes probable the truth of a proposition". ${ }^{11}$ We engage in an act of epistemic justification whenever we attempt to render our beliefs more plausible to others. Note that this definition does not make any claims as to the nature of the methods used or their potential soundness. Given this interpretative framework, early Christian authors were undoubtedly engaging in acts of epistemic justification. At the very low end of the socio-political pecking order, struggling to establish an identity, first against the venerable antiquity of Jewish law and Greek wisdom and later against splintering groups that would come to be proclaimed heresies, the unlikely message of a Messiah nailed to the cross surely required all of the epistemic justification it could muster and the earliest apologists were acutely aware of

4 Van Winden (1977: p. 190): “Comme interlocuteur Justin est donc favorable à la philosophie. Mais la discussion elle-même n'est pas favorable à la philosophie. Car Justin se laisse convaincre par le viellard que le Platonisme ne contient pas la vérité. En d'autres termes, ce passage aussi a un caractère anti-philosophique."

5 Chadwick (1993: p. 237). Félix (2014: p. 438) arrived at a similar conclusion and claimed that Justin "buscará mostrar con claridad la racionalidad del cristianismo, por el camino de la semejanza con la cultura helenística".

6 Tertullianus, De carne Christi 5.4: Crucifixus est dei filius; non pudet, quia pudendum est. Et mortuus est dei filius; credibile est, quia ineptum est. Et sepultus resurrexit; certum est, quia impossibile.

$7 \quad$ Sider (1980: p. 418).

8 Bochet (2008: p. 271): “[...] l'usage du paradoxe n'est pas une mise en cause de la raison; plus radicalment même, il en est une exigence".

9 Labhardt (1950: p. 166 et passim). Similarly, Frend (2008: p. 361) highlighted Tertullian's "utter rejection of pagan society and pagan philosophy".

10 Kaufmann (1991: p. 173).

11 Fumerton (2002: p. 205). For a good discussion of current philosophical theories of epistemic justification, see Swineburne (2001). I am using Fumerton's rather basic definition on purpose as discussing the earliest Christian literature in modern philosophical terms (such as internalism vs. externalism) would be anachronistic. 
the fact. As an example, Justin Martyr introduced one of the possible warrants of Christian faith as follows: ${ }^{12}$

\begin{abstract}
"Though we could bring forward many other prophecies, we forbear, judging these sufficient for the persuasion of those who have ears to hear and understand; and considering also that those persons are able to see that we do not make mere assertions without being able to produce proof, like those fables that are told of the so-called sons of Jupiter. For with what reason should we believe of a crucified man that He is the first-born of the unbegotten God, and Himself will pass judgment on the whole human race, unless we had found testimonies concerning Him published before He came and was born as man, and unless we saw that things had happened accordingly [...]?” (Transl. M. Dods \& G. Reith). ${ }^{13}$
\end{abstract}

Indeed, even Tertullian, uncontroversially considered to be rather inimical to philosophy and ratiocination, claimed that arguments may be presented in favour of Christian truth, namely the rule of faith, the antiquity of the Scripture, and the testimony of spiritual powers. ${ }^{14}$ Yet there is something rather specific in the methodology early Christian writers used to persuade their readers and listeners. In order to identify this specificity, I propose to differentiate between two basic modes of epistemic justification.

First, I term epistemic justification impersonal if and only if the truth value of a proposition is determined by a process which precludes any reference to special properties of the person affirming the proposition. If the truth-maker of a proposition cannot be any special property of the person affirming the proposition, arguments ex auctoritate are not to be admitted into the discussion. Impersonal epistemic justification not only is the norm in modern scientific discourse, but was, by and large, the norm in ancient Greek science and philosophy as well. ${ }^{15}$ It is true that Parmenides solemnly introduced his philosophical ideas as revealed by a goddess, ${ }^{16}$ yet one may consider this to be a topical libation to epic po-

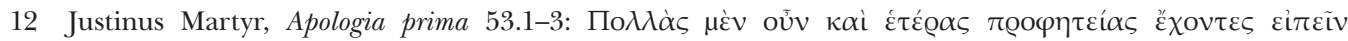

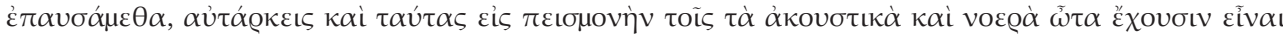

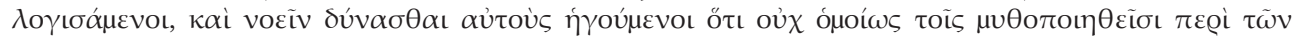

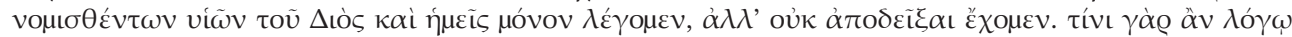

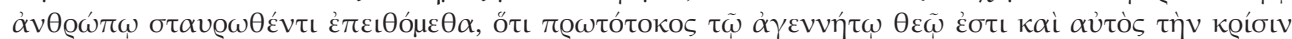

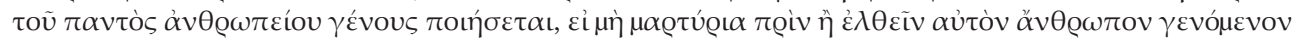

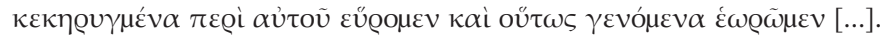

13 For convenience's sake, I am explicitly indicating translators of the Greek and Latin originals only in instances of longer citations. The full list of English translations used is supplied alongside the bibliography of primary sources.

14 Tertullianus, Apologeticum 46.1: ostendimus totum statum nostrum, et quibus modis probare possimus, ita esse sicut ostendimus, ex fide scilicet et antiquitate diuinarum litterarum, item ex confessione spiritalium potestatum.

15 The constraints of this paper prevent delving deeper into theories of truth, either ancient or modern. Suffice it to say that most ancient philosophers operated with a variety of correspondence-based theories,

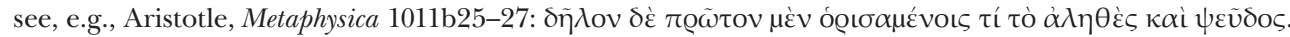

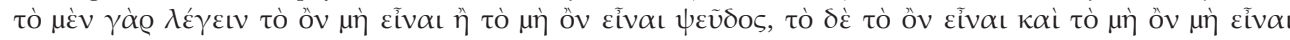
$\dot{\alpha} \lambda \eta \theta \dot{c} \varsigma$.

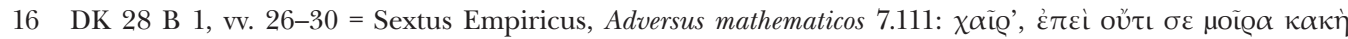

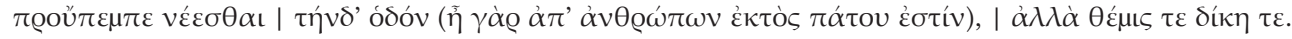


etry rather than an attempt to justify his statements by divine revelation. ${ }^{17}$ That is, after all, why his follower Zeno did not reference his teacher's special source of knowledge but constructed elegant thought experiments to support his attacks on the reliability of the senses. It is true that Empedocles tried to establish philosophical authority by invoking a Muse ${ }^{18}$ and presenting himself as an immortal god, ${ }^{19}$ yet these attempts are met with ridicule, echoed in an amusing story reported by Diogenes Laertius about how our godphilosopher hurled himself into Mount Etna to transform a sudden disappearance into apotheosis only to have his plan thwarted by the volcano, which eventually threw back a piece of his footwear and thus spoilt the plan. ${ }^{20}$

Cicero may be seen as representing the vast majority of ancient Greek philosophers when he required that "in discussion it is not so much authorities as determining reasons that should be looked for" ${ }^{21}$ Following this brief methodological statement, he proceeded to criticize the Pythagorean ipse dixit mode of argumentation, and it is probably symptomatic that Pythagorean society is considered to have been "a religious sect rather than a philosophical school" even by some modern scholars. ${ }^{22}$ One may well agree with Jonathan Barnes in his claim that not a single Greek philosophical or scientific text exists which defends its basic principles via an appeal to authority; ${ }^{23}$ and one might not agree completely with René Braun in the suggestion that the Christian concept of "revelation" is an anti-Greek term par excellence $e^{24}$ - Homer and Hesiod are certainly as Greek as it gets and their poems might surely be understood as having been "revealed" to them by the Muses - but I would surely consider "revelation" to be an anti-philosophical term.

Second, I term epistemic justification personal if and only if the truth value of a proposition is determined by a process which is based on reference to special properties of the person affirming the proposition. If the truth-maker of a proposition is a special property of the person affirming the proposition, arguments ex auctoritate are not only admitted into

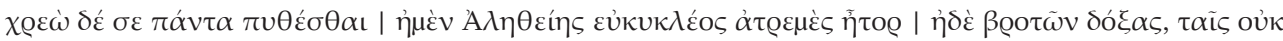

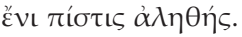

17 See, e.g., Granger (2007: p. 416): "In contrast with Xenophanes, they [sc. Parmenides and Empedocles] may be in sympathy with the old poetic tradition and its reliance upon the Muses."

18 DK 31 B 3 = Sextus Empiricus, Adversus mathematicos $7.125=$ DK 31 B 3: $\alpha \lambda \lambda \dot{\alpha} \theta \varepsilon o i ̀ ~ \tau \tilde{\omega} v \mu \varepsilon \dot{\varepsilon} \mu \alpha v i ́ \eta v$

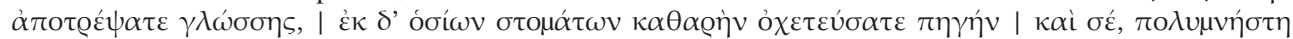

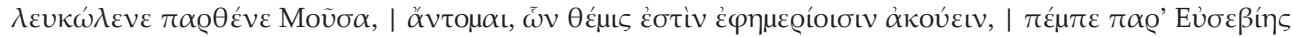

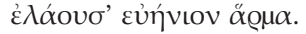

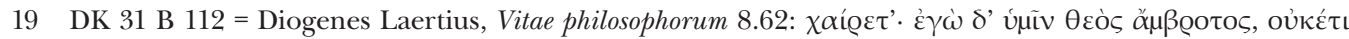

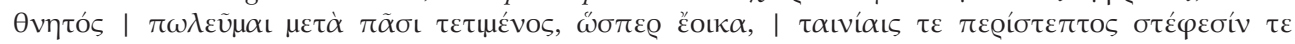
$\theta \alpha \lambda \varepsilon$ cíoıs.

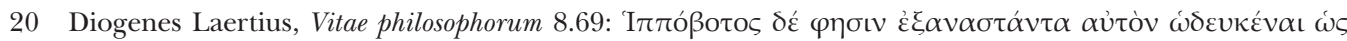

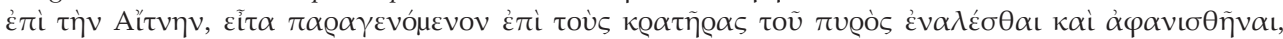

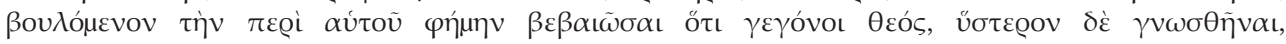

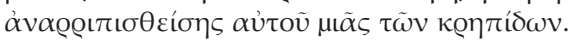

21 Cicero, De natura deorum 1.5.10: non enim tam in auctoritatis in disputando quam rationis momenta quaerenda sunt.

22 Guthrie (1962: p. 148).

23 Barnes (1997: p. 207).

24 Braun (1971: p. 242). 
the discussion but are intended to do heavy lifting in the process of persuading others. In what follows, I will demonstrate that the personal mode of epistemic justification is highly characteristic of early Christian discourse. In order to do so, I will use a slightly modified list of "warrants of Christian faith", originally developed by Anthony Guerra in his discussion of Tertullian..$^{25}$

\section{(1) Epistemic justification by miracles}

The functions that the earliest Christian writers attributed to miracles are by no means uniform, but there can be little doubt that miracles played a decisive role in their process of epistemic justification of Christian belief. With respect to the miracles performed by Jesus, Hendrik van der Loos in his already classical work on the subject identified four main functions, of which no less than three may be seen as directly connected with the process of epistemic justification: (1) proof of identity, (2) display of mercy, (3) means of arousing faith, and (4) sign. ${ }^{26}$ Notwithstanding some striking differences between the synoptics and John,${ }^{27}$ the miracles performed by Jesus are clearly supposed to prove his real identity as the Messiah to the reader and consequently validate the propositional content of anything he said. As it is not possible to discuss the miracles of Jesus systematically and exhaustively, several paradigmatic instances will have to suffice..$^{28}$

In Matthew, we read that "Jesus went throughout Galilee [...] curing every disease and every sickness among the people. So his fame spread throughout all Syria, and they brought to him all the sick, those who were afflicted with various diseases and pains, demoniacs, epileptics, and paralytics, and he cured them." ${ }^{29}$ Once the miracle-healer

25 Guerra (1991: p. 109) singled out the following five warrants: (1) scripture, (2) reason, (3) superior moral behavior, (4) spiritual testimony, and (5) tradition. It is not entirely clear what he includes under the heading "reason", but it seems that the term refers to a "natural theology" of sorts, comprising knowledge about God independent of revelation. While it is true that early Christian authors sometimes do argue along these lines, it will be shown that, at best, natural theology can provide only secondary support for their claims. I took the liberty of replacing said category with another warrant, namely the demonstration of supernatural power through miraculous works, which is clearly used by many early Christian authors as a means of epistemic justification. Modified and rearranged, the list of warrants I use herein is: (1) miracles, (2) superior moral behavior, (3) spiritual testimony and divine inspiration, (4) scripture and the fulfillment of prophecies, and (5) tradition.

26 Van der Loos (1960: pp. 241-251).

27 This is emphasized even in introductory textbooks, such as Ehrman (2012: pp. 182-184). Elsewhere, Ehrman (2009: p. 85) claimed that whereas "supernatural proofs of Jesus' identity were strictly off limits in Matthew, in John they are the principal reason for Jesus' miraculous acts". Kee (1986: p. 80) also noted that "Jesus [...] presents himself as the instrument of miracle only in order to meet the needs of the sick and the demon-possessed. He will not act in order to corroborate his own authority." All this might be true, yet from the point of the view of the reader, it is completely inconsequential that in Mark or Matthew Jesus is portrayed as discouraging the "divulgation" of his miraculous deeds, since the reader knows about them from the text itself and therefore identifies him as the Messiah.

28 The best recent systematic study of Jesus' miracles is Zimmermann (2013). The second volume in the series, discussing the miracles of the apostles, has been prepared for publication in late 2016.

29 Matthew 4, 23-24. 
career of Jesus is thus summarized, the author of Matthew continued with the Sermon on the Mount and Jesus teaching the moral substance of the "good news", and "the crowds were astounded at his teaching, for he taught them as one having authority ( $\omega \varsigma$

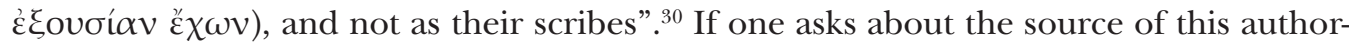
ity, miracles clearly play a major role. The various groups of Jews with whom Jesus had to compete for followers were hardly lacking moral precepts - what they did lack was the ability to legitimize these precepts by curing normally incurable medical conditions.

Another section of Matthew makes the function of miracles in an act of epistemic justification even clearer. Jesus reproached the cities where "most of his deeds of power

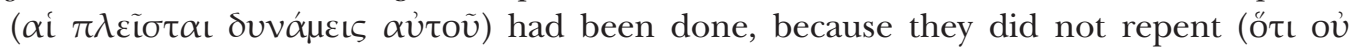
$\mu \varepsilon \tau \varepsilon v o ́ \eta \sigma \alpha v) " .{ }^{31}$ It stands to reason that in order to repent, the inhabitants of those cities would first have to recognize Jesus as the Messiah (thereby accepting what he said as true, which would give them proximate cause to repent). The reproach only makes sense if we presuppose, as Jesus here certainly does, that the epistemic justification is achieved by "deeds of power". As mentioned above, the miracles performed by Jesus in John are somewhat different from those in the synoptics. Those in John are less numerous but far more spectacular, and the author of the gospel explicitly presents them as acts of epistemic justification. To use but a single example: "Jesus did this, the first of his signs, in Cana of Galilee, and revealed his glory; and his disciples believed in him". ${ }^{32}$ The miracle

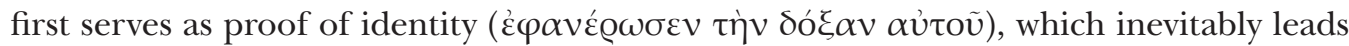

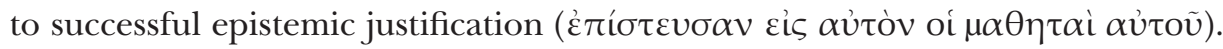

In the authentic Pauline epistles, Paul used the very same argumentative strategy in order to establish his authority as an apostle and justify his words and actions. ${ }^{33}$ Rebuking Jewish Christians in the church of Galatia for their tendency to rigidly uphold the Law, he asked: ${ }^{34}$

"Did you experience so much for nothing? - if it really was for nothing. Well then, does God

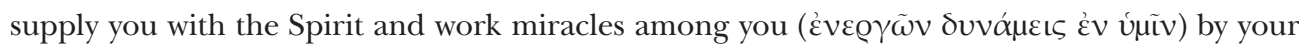
doing the works of the law, or by your believing what you heard?” (Transl. NRSV).

In 1 Corinthians, Paul noted that his speech and proclamation "were not with plausible

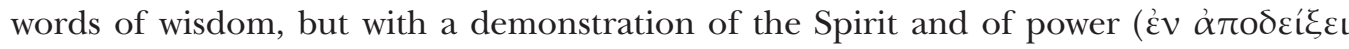

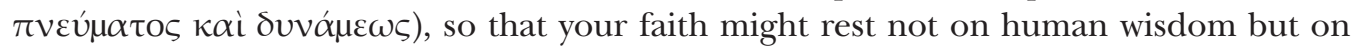

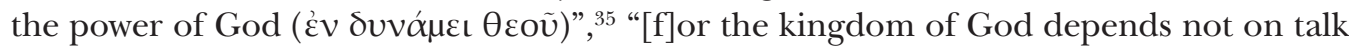

30 Matthew 7, 28-29.

31 Matthew 10, 20.

32 John 2, 11.

33 I find this to be uncontroversial communis opinio. As Kee (1986: p. 129) summarized, "[t]he ability to perform wonders, including healings, figures importantly in Paul's apologia for his apostolic ministry". Kelhoffer (2001: p. 183) added that "[a]lready by the time of Paul's writings, miracles had become an established part of the Christian tradition, a means of authenticating a particular leader's authority”.

34 Galatians 3, 4-5.

351 Corinthians 2, 4-5. 


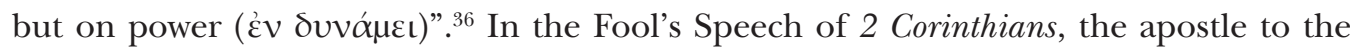
Gentiles again attempted to establish his authority by highlighting his power to produce miracles: "The signs of a true apostle were performed among you with utmost patience,

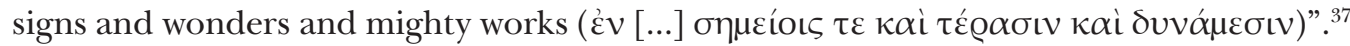
In the same vein, in Romans we read that Paul converted Gentiles "by word and deed,

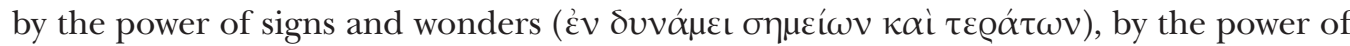
the Spirit of God". 38

Apocryphal literature of the first three centuries made even heavier use of miracles as a means of epistemic justification than did writings later awarded canonical status. ${ }^{39}$ Many clear examples are provided by the Infancy Gospel of Thomas, in which the reaction of crowds to the miracles performed by Jesus is explicitly described as awe ( $\dot{\xi} \xi \varepsilon \pi \lambda \alpha \gamma \eta \sigma \alpha \nu$;

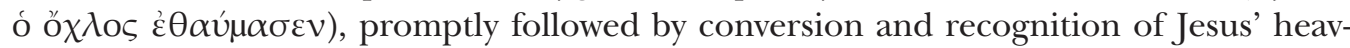

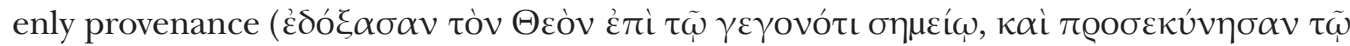

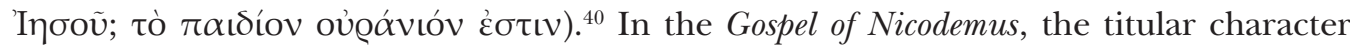
defends Jesus in front of Pilate precisely on the basis of his miraculous deeds: Jesus is

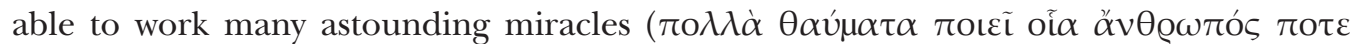

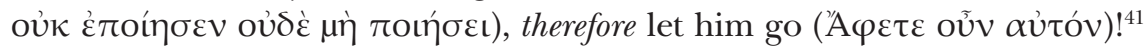

Apocryphal acts in particular display an abundance of miracles performed by apostles and the function of the miracle as a means of epistemic justification of Christian belief and a means of conversion is often stated explicitly. ${ }^{42}$ In its most radical form, miracles performed by apostles are framed in a sort of contest (agon) between the apostle of Christianity and a follower of a pagan god (or Satan). A typical example of this narrative structure can be seen in an episode from the Acts of John: While visiting the Temple of Artemis in Ephesus, John the Apostle harshly reproached the local population (just as Jesus reproached Chorazin, Bethsaida, and Capharnaum in Matthew, see above) for not converting and accepting the Christian faith in spite of many miracles performed

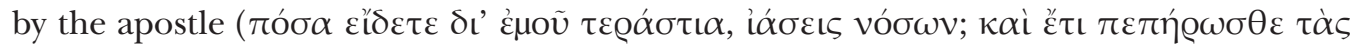

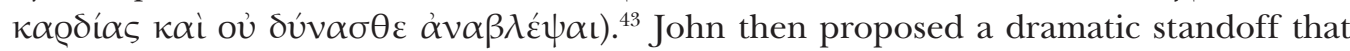

361 Corinthians 4, 20.

372 Corinthians 12, 12.

38 Romans 15, 18-19.

39 For Piñero \& Del Cerro (2004: p. 91), the main difference between canonical and apocryphal miracles lies in their perceived "utility". In canonical texts, almost all miracles are "useful" (útiles), in the sense of directly helping the person afflicted by disease, demon, death, etc. In apocryphal literature, there are many miracles that are not "useful" in this sense (inuitiles). It may, however, be plausibly argued that the utility of the miracles considered by Piñero \& Del Cerro to be "useless" lies precisely in the demonstration of godly power as an extremely effective means of conversion; their function is to epistemically justify the content of the apostle's teaching.

40 Infancy Gospel of Thomas 9.3 \& 18.2.

41 Gospel of Nicodemus 5.1.

42 See, e.g., Acts of Andrew 4.2 or Acts of John 30.2. For an overview of miracles in the apocryphal acts, including a valuable discussion of the "competition" between Christian and pagan miracle workers, see Bremmer (2002). 
consisted of Ephesians praying to Artemis and John to praying to his god in order to find out who is mightier (and who, therefore, is the true god). The results of this agon are quite remarkable, as John, with the help of his god, achieved a crushing victory, quite literally in fact, since he destroyed a good part of the temple and the altar of the pagan goddess while killing her priest and then resurrecting him after a short while. The outcome of this showdown is unsurprising. Ephesians converted in droves because they had

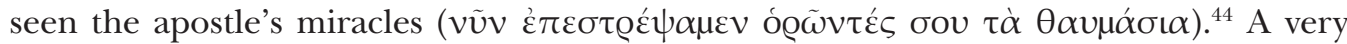
similar episode is found in the famous agon fidei between Peter and Simon the Mage in the Acts of Peter with identical results. ${ }^{45}$

Although the ability to work miracles in early Christian literature is usually limited to Jesus and his apostles, we occasionally find testimonies of ordinary members of Christian communities performing miracles in Jesus' name as well. ${ }^{46}$ Justin Martyr reported "many of our people exorcising the possessed in the name of Jesus Christ"; ${ }^{47}$ Theophilus of Antioch wrote that even "up to the present day those who are possessed by demons

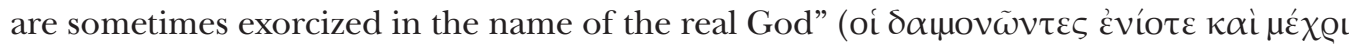

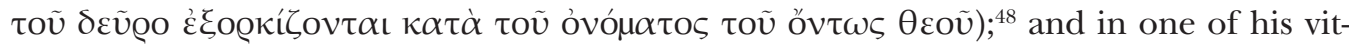
riolic attacks against philosophers, Tertullian contemptuously noted that philosophers (in contrast to Christians) did not have the power to exorcize demons. ${ }^{49}$ A valuable summary of the role of miracles in the epistemic justification of Christian faith is provided by Origenes: ${ }^{50}$

44 Acts of John 42.2.

45 Acts of Peter 16.2-3: Iam plurima turba fraternitatis reuersa est per me et per quae signa fecisti in nomine meo. Habebis autem agonem fidei ueniente sabbato et conuertentur multo plures de gentibus et de Iudaeis in nomine meo in me contumeliatum, derisum, consputum. Ego enim me tibi praestabo petenti [te] signa et prodigia, et conuertes multos, sed habebis contrarium Simonem per opera patris sui. Sed omnia eius adprobabuntur carmina et magica figmenta. Nunc autem noli cessare, et quoscumque tibi misero in nomine meo fundabis. The agon fidei takes place in Acts of Peter 25-28; 31-32.

46 On the topic of exorcisms (and other miracles) performed by ordinary Christians, see especially Kelhoffer (1999), who presupposed a "resounding boom [sc. of ordinary believers as workers of miracles] in the early centuries of the Christian movement" and Kollmann (1996: pp. 375-376), who arrived at a virtually identical conclusion: "Für das frühe Christentum läßt sich eine breite Bewegung von Wandermissionaren nachweisen, die ihre Legitimität und die Art ihres Auftretens entscheidend von der im Kern authentischen Aussendungstradition Lk 10,1-12par ableiteten. Die wesentlichen Charakteristika sind neben Verkündigungstätigkeit ein Bewirken von Dämonenaustreibungen und Krankenheilungen [...].”

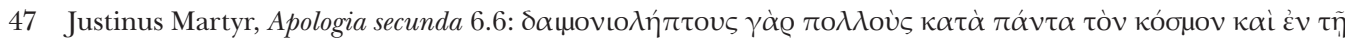

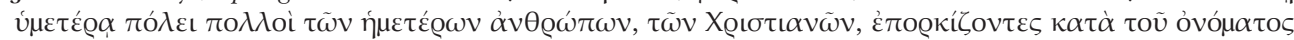

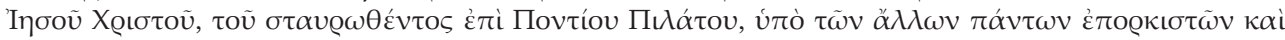

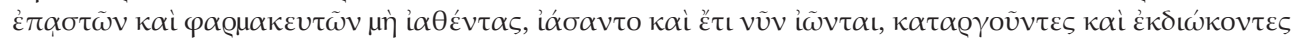

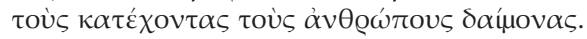

48 Theophilus Antiochenus, Ad Autolycum 2.8.

49 Tertullianus, Apologeticum 46.4: Nomen hoc philosophorum daemonia non fugiunt.

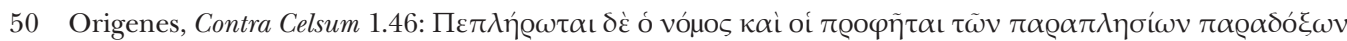

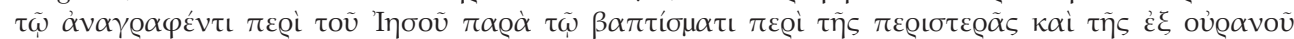

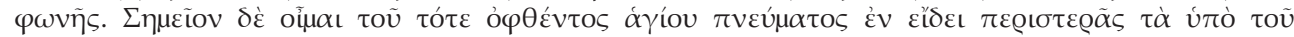

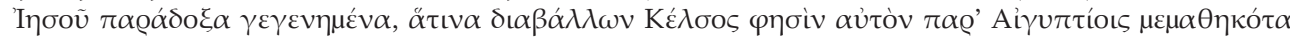

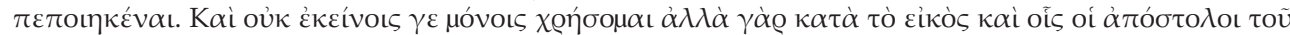

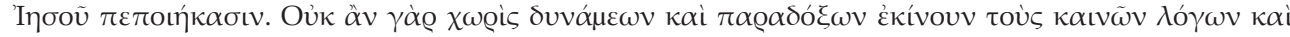


"The law and the prophets are filled with accounts as miraculous as that recorded of Jesus at the baptism about the dove and the voice from heaven. But I think that the miracles performed by Jesus are evidence that the Holy Spirit was seen then in the form of a dove, although Celsus attacks them by saying that he learnt how to do them among the Egyptians. And I will not mention these only, but also, as is reasonable, those which were done by Jesus' apostles. For without miracles and wonders they would not have persuaded those who heard new doctrines and new teachings to leave their traditional religion and to accept the apostles' teachings at the risk of their lives. Traces of that Holy Spirit who appeared in the form of a dove are still preserved among Christians. They charm daemons away and perform many cures and perceive certain things about the future according to the will of the Logos." (Transl. H. Chadwick).

Notwithstanding the necessarily limited selection of source material, it seems to me uncontroversial to conclude that one of the most important (albeit surely not singular) functions of miracles performed by Jesus, his apostles, and (to a lesser extent) other members of the Christian community in ante-Nicene Christianity is the epistemic justification of Christian beliefs. The power of miracles bestows an aura of authority on whoever is able to perform them and miracle stories are, without a doubt, valuable assets for missionary work. ${ }^{51}$ If we now attempt to identify the underlying logical form of epistemic justification by miracles, it may be reconstructed in the following slightly simplified manner:

$(p 1)$ If individual $x$ possesses property $P$, with $P$ being the ability to perform true miracles, then the truth value of a proposition expressed by $x$ is "true".

$(p 2)$ Jesus, the apostles, and some of their followers demonstrated the possession of $P$ (the ability to perform true miracles).

(c) Propositions expressed by Jesus, the apostles, and some of their followers are true.

By linking the specific abilities of an individual with the truth value of the propositions they express, the conditional of the first premise $(p 1)$ clearly amounts to the personal mode of epistemic justification. $P 1$ is, of course, not always stated explicitly (early Christian literature does not consist of logical treatises), yet it has to be tacitly presupposed for the conclusion $(c)$ to hold. Furthermore, the second premise $(p 2)$ is not without complications. How do we know, for instance, that Jesus really rose from the dead? Paul provides a tentative answer: We know it because he "appeared to Cephas, then to the twelve. Then he appeared to more than five hundred brothers and sisters at one time, most of whom are still alive, though some have died. Then he appeared to James, then

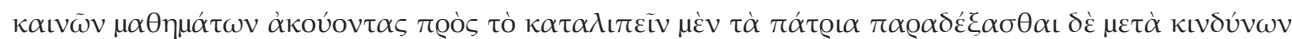

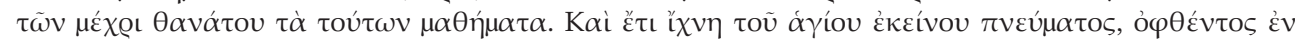

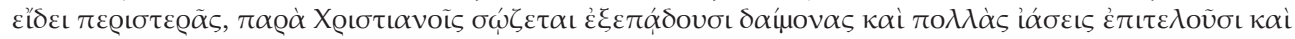

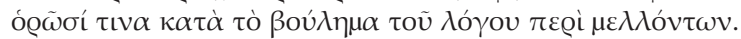

51 Larmer (2011: p. 46): "The claim that Jesus fulfilled the Old Testament prophecies of a coming Messiah and that his miracles are confirmation that in him the Messiah has arrived was regarded by first- and second-century Christian apologists as the strongest argument for Christianity."; Kollmann (2011: p. 66): "Wundergeschichten dienten, daran kann wenig Zweifel bestehen, im Rahmen der urchristlichen Missionstätigkeit dazu, die Hoheit Jesus zu erweisen und die Konkurrenz aus dem Felde zu schlagen. Sie wollen zum Glauben an Jesus animieren und bedienen sich einer in der antiken Welt üblichen Form der Werbung." 
to all the apostles. Last of all, as to one untimely born, he appeared also to me." ${ }^{2}$ In other words, we know it because it has been reported to us by others. For the effective use of miracles as a means of epistemic justification, the concept of a reliable witness is central. ${ }^{53}$ This brings us to the second warrant of Christian belief.

\section{(2) Epistemic justification by superior moral behaviour}

"If with merely human hopes I fought with wild animals at Ephesus, what would I have gained by it?" ${ }^{44}$ In his struggle to establish the authority of an apostle, Paul made numerous appeals to his own superior moral character, ${ }^{55}$ of which the most striking example is provided by the powerful apophatic argumentation in his Fool's Speech, ${ }^{56}$ where moral superiority is rhetorically connected with profound humility. A witness is a good witness only if he or she can be trusted, and so epistemic justification of Christian faith by the superior moral behaviour of Jesus and his followers eventually became commonplace in the works of early Christian authors and their attempts to justify their beliefs.

Ignatius of Antioch, undoubtedly drawing on Paul, argued against docetic views of Jesus as follows: "But if, as some atheists (that is, unbelievers) say, he suffered in appearance only (while they exist in appearance only!), why am I in chains? And why do I want to fight with wild beasts? If that is the case, I die for no reason; what is more, I am telling lies about the Lord" ${ }^{57}$ Of course, Ignatius did not die for no reason; therefore, he is not telling lies about the Lord. As he noted elsewhere, "I am God's wheat, and I am being ground by teeth of the wild beasts, so that I may prove to be pure bread." 58 In another letter, Ignatius complained that "certain people" ( $\tau \iota v \varepsilon \varsigma$ ) were stubbornly denying Jesus and " $[\mathrm{n}]$ either the prophecies nor the law of Moses have persuaded them, nor, thus far,

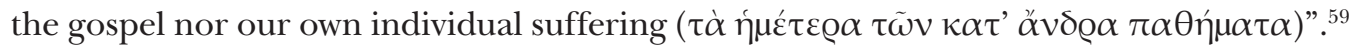
For both Paul and Ignatius, the preparedness of Christians (including, of course, them-

521 Corinthians $15,5-8$.

53 As Hauck (1988: p. 249) notes, the unreliability of witnesses is one of the objections that achieved topical status in pagan criticisms of the early Christian movement.

541 Corinthians 15, 32.

55 Again, this seems to be umproblematic communis opinio. For Meunier (2006: p. 331), "avant d'être un bon théologien ou un fournisseur de concepts, il [sc. Paul] est un homme voué au Christ. Telle est aux yeux des Pères la source de son authorité theologique." Dassmann (2009: p. 244), having Paul in mind in particular, wrote that "[e]l prestigio de los apóstoles queda reforzado por su martirio en Roma [...]." Frend (2008: pp. 85-86) highlighted the fact that "Paul passionately believed that suffering, beatings and death were the symbol of his own right to be called an apostle. [...] In Paul's mind suffering for the faith and the task of witnessing to it were equally urgent and inextricably interwoven."

562 Corinthians 11, 16 - 12, 10.

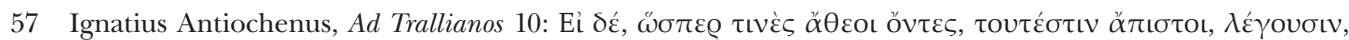

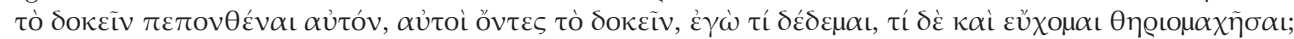

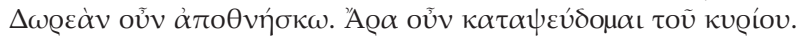

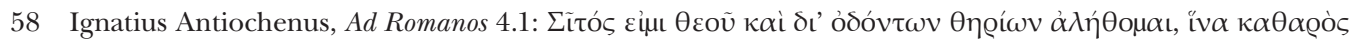
ă

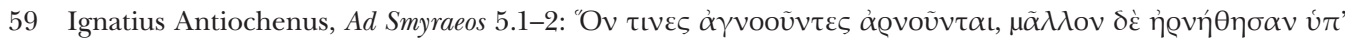


selves) to undergo suffering, and even death, is explicitly put forward as an act of epistemic justification as a means of persuasion.

The prototypical use of epistemic justification by superior moral behaviour may be found in the phenomenon of martyrdom, ${ }^{60}$ which came to exercise profound influence on the later development of Christianity, both literal and historical - influence so great, in fact, that the very thought of martyrdom as a means of epistemic justification still had the power to enrage Nietzsche in the late nineteenth century, as we can see in his writing that "[t]he idea that martyrs prove anything about the truth of a matter is so far from being true that I would like to deny that martyrs have ever had anything to do with the truth" ${ }^{61}$

To limit ourselves to only one representative example, we may use the Martyrdom of Polycarp, which combines warrants by both miracles and superior moral behaviour. After receiving a vision that foretold his martyrdom, Polycarp is lead to trial, refuses to abandon his belief, and receives the death penalty in the form of being burned alive. Unshaken by his impending doom, Polycarp achieves the pinnacle of moral perfection, which is complemented by a miracle: ${ }^{62}$

"And as a mighty flame blazed up, we saw a miracle (we, that is, to whom it was given to see), and we have been preserved in order that we may tell the rest what happened. For the fire, taking the shape of an arch, like the sail of a ship filled by the wind, completely surrounded the body of the martyr; and it was there in the middle, not like flesh burning but like bread baking or like gold and silver being refined in a furnace. For we also perceived a very fragrant aroma, as if it were the scent of incense or some other precious spice." (Transl. M. W. Holmes).

Eventually a sword accomplished what the fire could not, but not without a final miracle - a dove broke out of his wound and the martyr's blood extinguished the fire. The moral of the story? "This man was certainly one of the elect, the most remarkable Polycarp, who proved to be an apostolic and prophetic teacher in our own time, bishop of the catholic church in Smyrna" ${ }^{63}$ Polycarp is proven innocent, Christian belief is proven to be true, and, as Tertullian remarked, "[t]he oftener we are mown down by you, the

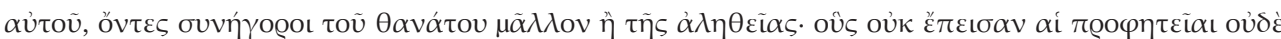

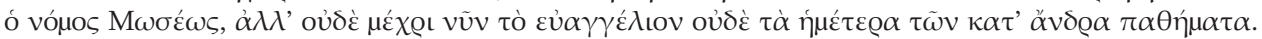

60 Once again, it is not possible to survey martyrological literature systematically. For a classical account of early Christian martyrdom, see Frend (2008) and in particular recent volumes by Candida Moss (2010; 2012; 2013).

61 Nietzsche (2005: p. 52).

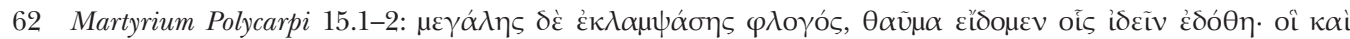

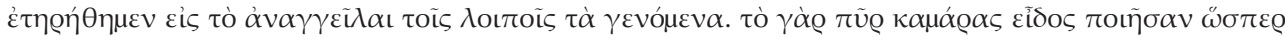

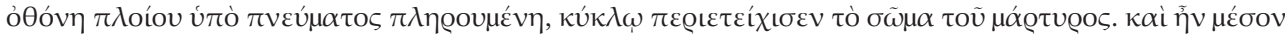

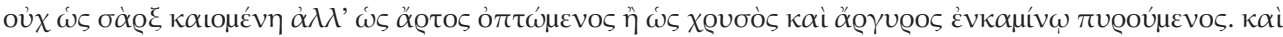

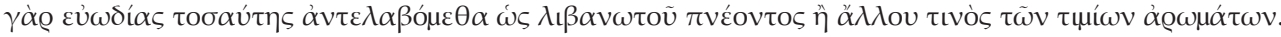

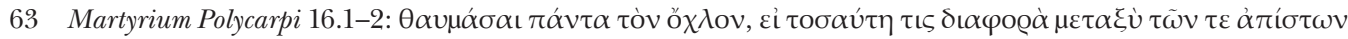

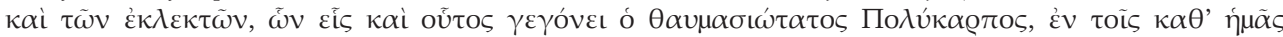

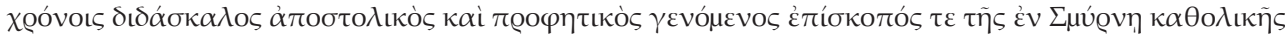

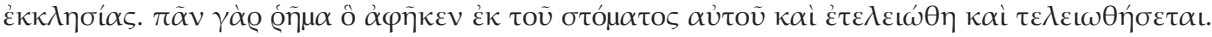


more in number we grow; the blood of Christians is seed" ${ }^{64}$ Pace Nietzsche, the view of martyrdom in early Christianity is, without any doubt, "the greatest proof of faith" (probatio maxima fidei), ${ }^{65}$ proof that extends far beyond the first few centuries. As Candida Moss summarized, "for much of the Christian era, martyrdom was viewed [...] as an indication of Christianity's unique possession of religious truth. If Christians alone were prepared to die for their beliefs, it was thought, then there must be something special about Christianity." ${ }^{66}$

However, not every epistemic justification by superior moral behaviour was necessarily connected with violent suffering and martyrdom. In Didache, for instance, we find the following criterion for differentiating between true and false apostles: ${ }^{67}$

\begin{abstract}
"Now concerning the apostles and prophets, deal with them as follows in accordance with the rule of the gospel. Let every apostle who comes to you be welcomed as if he were the Lord. But he is not to stay for more than one day, unless there is need, in which case he may stay another. But if he stays three days, he is a false prophet. And when the apostle leaves, he is to take nothing except bread until he finds his next night's lodging. But if he asks for money, he is a false prophet." (Transl. M. W. Holmes).
\end{abstract}

Once again, the truth or falsehood of a proposition is effectively determined as a function of the perceived moral profile of the individual expressing that proposition. Humble apostles are true apostles; if there is reason to doubt an individual's moral character (occasioned by staying for multiple days or asking for money and thereby falling under suspicion of greed), there is reason to distrust what the individual has to say. Moreover, this model of argumentation is not alien even to well-educated proponents of early Christianity. For instance, as Fritz-Peter Hager observed, ${ }^{68}$ the two main reasons why Tertullian criticized philosophers are: (1) there is a clear discrepancy between their theories and the way they live their lives, and (2) they stole their teaching from the prophets and disfigured it. Needless to say, both reasons are clear instances of what could be called an inverse of warrant by superior moral behaviour - just as virtue is thought to engender

64 Tertullianus, Apologeticum 50.13: Etiam plures efficimur, quotiens metimur a uobis: semen est sanguis christianorum! Epistemic justification and martyrdom is explicitly linked in also Origen's work. As Frend (2008: p. 392) noted, "The Exhortation to Martyrdom represents Origen as the rebel. In words which echo Josephus, Against Apion (1.8.42), he claims that Christianity was true because people were prepared to die for it."

65 Martyrium Montani 14.9: hoc enim est propter Christum pati, Christum etiam exemplo sermonis imitari et esse probationem maximam fidei. O exemplum grande credendi!

66 Moss (2012: p. 23).

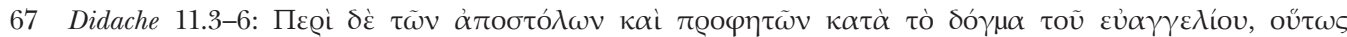

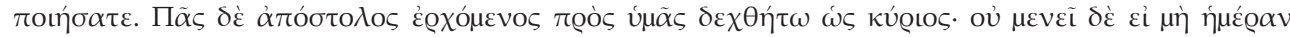

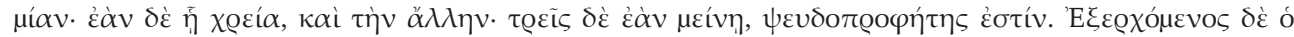

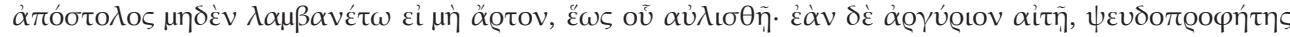

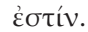

68 Hager (1978: pp. 76-77). See also Scaglioni (1972: p. 186), who seems to have generalized this observation to cover all of early Christianity: "Secondo una linea di attenzione che era già comunissima tra gli scrittori cristiani, viene colpita qui - in primo luogo - l'inefficienza morale della sapienza mondana del filosofo." 
truth, twisted morality is thought to produce falsehoods.

This line of thought is further extended to reach the heights of the Greco-Roman pantheon. Early Christian apologists (just as Xenophanes many centuries before them) were quick to point out the moral shortcomings of the Olympians in order to argue for their non-existence. Aristides of Athens lamented the fact that pagans took their gods for rolemodels and committed all sorts criminal and impious acts, polluting both the heavens and the earth with their evil deeds. ${ }^{69}$ When Athenagoras spoke about the "absurdity"

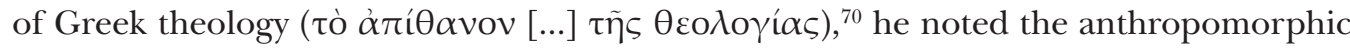
character of Greco-Roman deities and their domination by passions in particular. He had only rhetorical questions for the Greeks: ${ }^{71}$

\begin{abstract}
"What nobility or value is there in such an account for us to believe that Cronus, Zeus, Core, and the rest are gods? [...] Do they not reject this mass of impious nonsense concerning the gods? Heaven is castrated; Cronus is bound and cast down into Tartarus; the Titans revolt; the Styx dies in battle (already this shows that they regard them as mortals); they fall in love with each other; they fall in love with human beings ...” (Transl. William R. Schoedel).
\end{abstract}

Following a tour de force of cataloguing all sorts of perceived moral blemishes among the Greek gods, Clement of Alexandria ironically added: ${ }^{72}$

"Let such gods as these be worshipped by your wives, and let them pray that their husbands be such as these - so temperate; that, emulating them in the same practices, they may be like the gods. Such gods let your boys be trained to worship, that they may grow up to be men with the accursed likeness of fornication on them received from the gods." (Transl. William Wilson).

I do not believe it necessary to present the full list of early Christian authors who criticized pagan polytheistic religions and drew ontological conclusions about the existence or non-existence of Greco-Roman deities on the basis of their moral profiles. ${ }^{73}$ It is

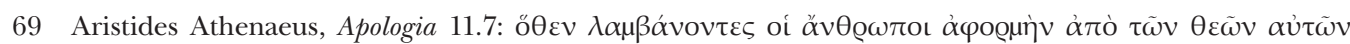

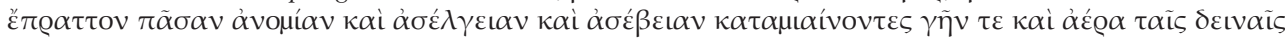

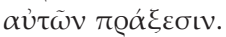

70 Athenagoras, Legatio pro Christianis 20.1.

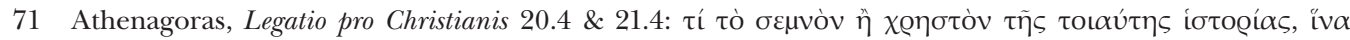

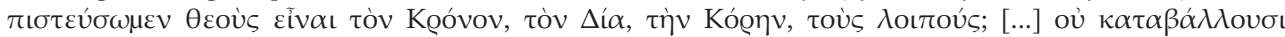

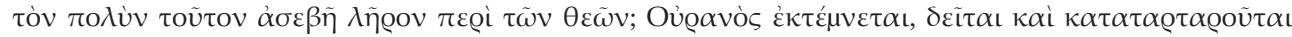

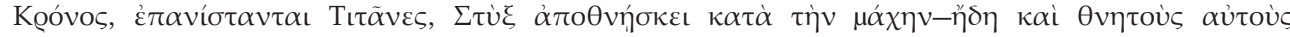

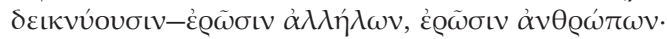

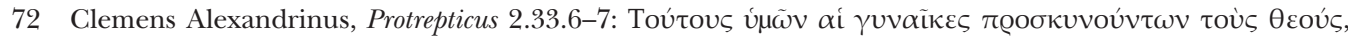

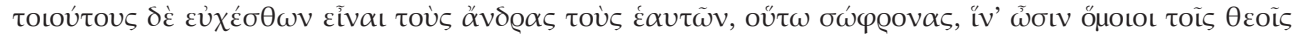

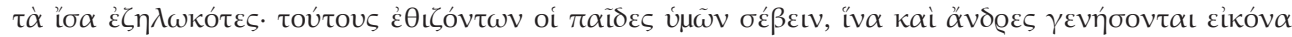

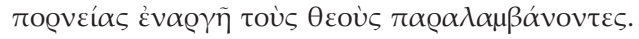

73 One might add Justinus Martyr, Apologia prima 21 \& Apologia secunda 12. A detailed study of Justin's critique of pagan gods is supplied by Munier (1988: pp. 94-96), concluding with the observation that "Justin reprend aussi et amplifie l'argument des transformations morales opérées par le christianisme, qui avait servi à Aristide, pour prouver la vérité et la sainteté de la religion chrétienne”; for more, see Theophilus 
enough to emphasize the connection between immorality and non-existence (falsehood) on the one side and superior morality and existence (truth) on the other. ${ }^{74}$ To summarize epistemic justification by superior moral behaviour in the simplified logical form used above:

$(p 1)$ If individual $x$ possesses property $P$, with $P$ being superior moral behaviour, especially in face of great cost to the well-being of $x$, then the truth value of a proposition expressed by $x$ is "true".

$(p 2)$ Jesus, the apostles, and early Christian martyrs demonstrated the possession of $P$ (superior moral behaviour).

(c) Propositions expressed by Jesus, the apostles, and early Christian martyrs are true.

The inverse would, of course, apply to pagan philosophers and the deities they worship: martyrs prove the truth of the belief they are offering their life for and, in contrast, philosophers' immoral conduct unmasks their teachings as falsehoods and the immoral conduct of the pagan gods unveils them as non-existent false idols.

\section{(3) Epistemic justification by divine inspiration}

If the gospels and the acts of the apostles, both canonical and apocryphal, relied heavily on warrants by miracles and superior moral behaviour, another important early Christian literary genre, namely apocalypses, sought to establish authority by means of epistemic justification by spiritual testimony and divine inspiration, by which I understand any appeal to a supernatural source for the knowledge that is being communicated. In the only canonical writing belonging to this genre, the introduction explicitly states

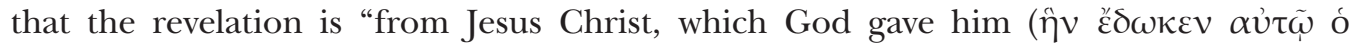
$\theta \varepsilon o ́ s)$ to show his servants what must soon take place; he made it known by sending his angel to his servant John (

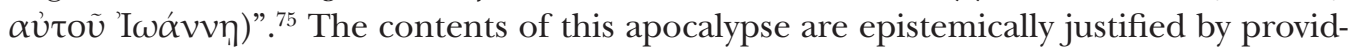
ing a link to the person "publishing" the content ("John") from the ultimate, unerring source of knowledge (God) via trustworthy mediators (the angel, Jesus).

Warrant by spiritual testimony is obviously not limited to apocalypses (canonical or otherwise) but also features heavily in Paul's epistles, which is not surprising, especially if we assume, with David Aune, that Paul is the "functional equivalent" of an Old Testament prophet, although he never uses this term to describe himself. ${ }^{76}$ The apostle was "sent neither by human commission nor from human authorities, but through Jesus

Antiochenus, Ad Autolycum 1.9 \& 3.3 or Tatianus, Oratio ad Graecos 8-11 et passim.

74 Kühneweg (1988: p. 113) highlighted the general argument from superior moral behaviour in early Christianity by claiming that "die Praxis [ist] ein so wesentliches Element des Christentums, kann sie auch als Argument für seine Wahrheit dienen.”

75 Revelation of John 1, 1-2.

76 Aune (1983: p. 248): “Paul often designates himself an 'apostle,' but never a 'prophet.' Modern scholars, however, are quite willing to categorize him as a prophet. From the standpoint of early Christianity, the role of apostle appears to have been a functional equivalent of the OT prophet." 


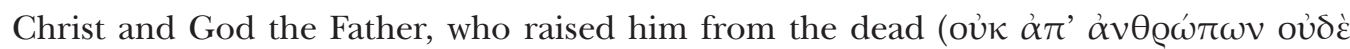

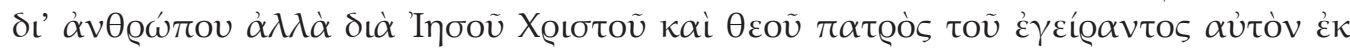
$v \varepsilon \kappa \varrho \tilde{\omega} v) ",{ }^{77}$ with Paul further clarifying that "the gospel that was proclaimed by me is not of human origin; for I did not receive it from a human source, nor was I taught it,

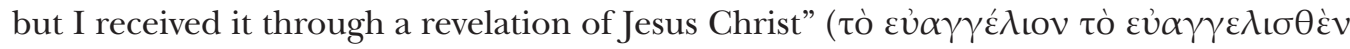

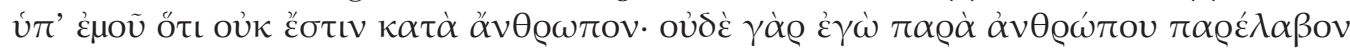

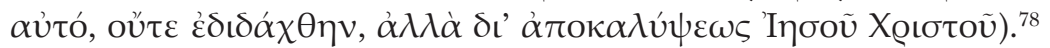

Elsewhere, Paul noted that "these things God has revealed to us through the spirit"

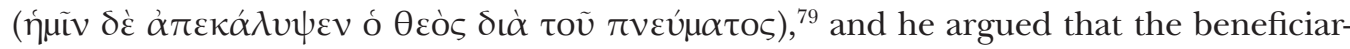
ies of this special kind of knowledge (that is, knowledge provided "directly" from and by God) were exempt from any further obligations to produce additional proof because "[t]hose who are spiritual discern all things, and they are themselves subject to no

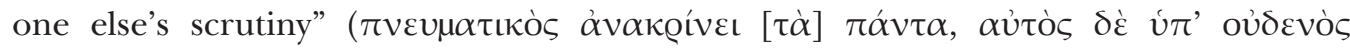
$\dot{\alpha} v \alpha \kappa \varrho i ́ v \varepsilon \tau \alpha \iota) .{ }^{80}$ Finally, the role of the Spirit is clearly spelled out in 2 Corinthians, where Paul, just like Homer almost a thousand years before him, claimed to know nothing. For Homer, all knowledge comes from a Muse, the warden of memory; ${ }^{81}$ for Paul, it comes from the Spirit and, ultimately, God: "Not that we are competent of ourselves to claim

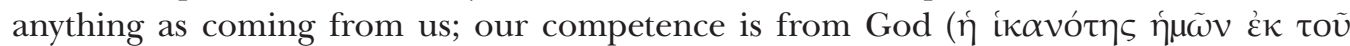
$\theta \varepsilon o \tilde{v})$, who has made us competent to be ministers of a new covenant, not of letter but of spirit; for the letter kills, but the Spirit gives life". ${ }^{82}$

For later Christian authors, spiritual testimony as a means of authentication usually complemented an apostle's immediate relationship with Jesus. ${ }^{83}$ For Justin Martyr, gifts of the Spirit consisted of spiritual wisdom, prophecy, and the power to perform miracles. ${ }^{84}$ Irenaeus of Lyons assured his readers that "after our Lord rose from the dead, [the apostles] were invested with power from on high when the Holy Spirit came down [upon them], were filled from all [His gifts], and had perfect knowledge" ${ }^{85}$ As Denis Farkasfalvy explained, ${ }^{86}$ the apostles in Irenaeus' treatise Against Heresies "are presented

77 Galatians 1, 1.

78 Galatians 1, 11-12.

791 Corinthians 2, 10.

801 Corinthians 2, 15.

81 Homerus, Ilias 2.485-486.

822 Corinthians 3, 5-6.

83 See, e.g., Tertullianus, De praescriptione haereticorum 22.3, 8-10: Quis igitur integrae mentis credere potest aliquid eos ignorasse quos magistros Dominus dedit, indiuiduos habens in comitatu in discipulatu in conuictu, quibus obscura quaeque seorsum disserebat, illis dicens datum esse cognoscere arcana quae populo intellegere non liceret? [...] Dixerat plane aliquando: Multa habeo adhuc loqui uobis, sed non potestis modo ea sustinere, tamen adiciens: Cum uenerit ille spiritus ueritatis, ipse uos deducet in omnem ueritatem, ostendit illos nihil ignorasse quos omnem ueritatem consecuturos per spiritum ueritatis repromiserat. Et utique impleuit repromissum, probantibus actis apostolorum descensum spiritus sancti.

84 Morgan-Wynne (1984: p. 176).

85 Irenaeus, Adversus haereses 3.1.1: Postea enim quam surrexit Dominus noster a mortuis, et induti sunt supervenientis Spiritus sancti virtutem ex alto, de omnibus adimpleti sunt, et habuerunt perfectam agnitionem.

86 Farkasfalvy (1968: p. 323). 
as entirely depending on Christ, having no other task but to channel to mankind the revelations of the Incarnate Word", but the bishop of Lyons also "declares that it is through the actual and active presence of the Spirit that the apostles carry out their preaching".

Notwithstanding minor differences (notably the validity of extra-apostolic appeals to spiritual testimony in Montanism, embraced at one point by Tertullian), the basic mechanism of warrant by spiritual testimony is similar to the epistemic justifications of faith by miracles and superior moral behaviour introduced above. It may also be summarized in a simplified logical format:

$(p 1)$ If individual $x$ possesses property $P$, with $P$ being special access to the ultimate source of knowledge (God), either directly or by means of reliable mediation (an angel, the Spirit, etc.), the truth value of a proposition expressed by $x$ is "true".

$(p 2)$ Jesus and the apostles demonstrated the possession of $P$ (special access to the ultimate source of knowledge).

(c) Propositions expressed by Jesus and the apostles are true.

Epistemic justification by spiritual testimony also constitutes an instance of personal epistemic justification as the proposition's truth value is dependent on the unique personal access to the ultimate source of knowledge and independent of any external verification.

\section{(4) Epistemic justification by prophecy fulfilment}

Prima facie, one could question the inclusion of arguments from Scripture under the heading of personal epistemic justification because they bear superficial resemblance to a well-accepted and entirely impersonal type of epistemic justification, namely the evaluation of hypotheses according to the success or failure of their predictions. From this vantage point, the prophets of the Old Testament were making predictions about the coming of the Messiah that were corroborated (that is to say, epistemically justified) by the appearance of Jesus in Galilee and Jerusalem. This is undoubtedly how early Christian authors understood the issue.

The core of the argument Justin Martyr made in favour of the plausibility of Christian belief consists of the fulfilment of such prophecies, ${ }^{87}$ an argument, incidentally, that played a key role in his personal conversion. ${ }^{88}$ Of course, it is not only Jesus' redemptive

87 Justinus Martyr, Apologia prima 31-53. For a detailed analysis of this argument in Justin's works, see Skarsaune (1987). De Vogel (1978: p. 370) highlighted the fact that for Justin, the ultimate argument in favour of the truth of Christianity is precisely the fulfilment of prophecies, not "philosophical" (impersonal) argumentation: "The argument of the fulfilment of the prophecies is for him 'proving', not any argument from Greek philosophy. This is a remarkable fact, but it is true.”

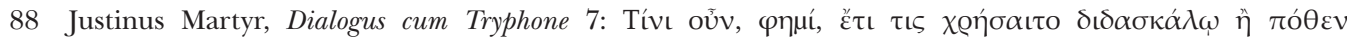

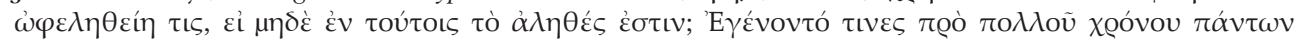

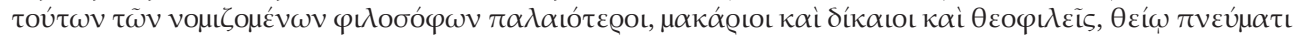

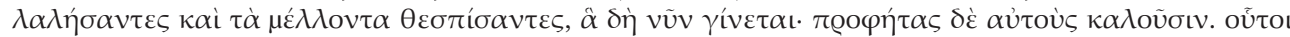

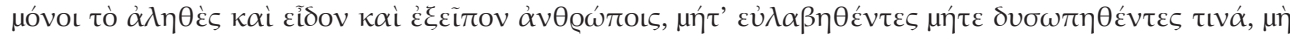

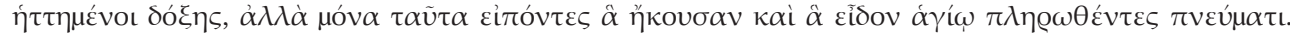


death that was prophetically predicted. To use another example, Tertullian made the same argument about the persecution of Christians: ${ }^{89}$

"All that is taking place around you was fore-announced; all that you now see with your eye was previously heard by the ear. [...] While we suffer the calamities, we read of them in the Scriptures; as we examine, they are proved. Well, the truth of a prophecy, I think, is the demonstration of its being from above." (Transl. S. Thelwall).

Tertullian, in other words, is working with a concept scholars termed "historical correspondence theory" ${ }^{90}$ or "historical rationality" consisting of the "perfect correspondence between what was foretold in the Old and fulfilled in the New Testaments". ${ }^{91}$ Scripture, legitimized by the fulfilment of the prophecies it contains, is considered to be divinely inspired; also for Irenaeus "the Scriptures are indeed perfect, since they were spoken by the Word of God and His Spirit". ${ }^{92}$

From what has just been presented, the inclusion of warrant by Scripture under the personal mode of epistemic justification does not seem to make much sense. Granted, some authors, such as Irenaeus, consider the prophets to have been divinely inspired, which would point us in the direction of a warrant by spiritual testimony as discussed above, but the argument from the prophecies is established as a perfect correspondence between a set of predictions and their fulfilment in the coming of Christ. As Bernard Sesboüé noted in discussing this type of argument in Irenaeus, "not only is the prophecy a proof of the event [sc. of Christ's coming], but the event becomes in its turn the proof of the prophecy: Word Incarnated is sent just as it has been announced". ${ }^{93}$

Setting aside the obvious issue of circularity, the reason why warrant by Scripture belongs firmly to the personal mode of epistemic justification lies elsewhere. In order for a warrant by Scripture to hold, it has to first be established that Jesus was Christ, the Messiah foretold by Jewish prophets. After all, Jesus could have well been an impostor, only claiming to be the Messiah while not being one - in fact, this is precisely what many of his contemporaries thought and Jesus was by no means the only one to claim the title.$^{94}$ Only if Jesus really is the Messiah does it make sense to argue from the fulfilment of Scripture; if Jesus is not the Messiah, the prophecies cannot be considered to have been fulfilled in him and the argument is void.

One may ask, with Jossa (2003: p. 172), whether these lines are fiction or historical reality: "Non sappiamo se sia stata effettivamente la realtà dei fatti o se siamo in presenza soltanto di un finzione letteraria."

89 Tertullianus, Apologeticum 20.2-3: Quicquid agitur, praenuntiabatur; quicquid uidetur, audiebatur [...] Dum patimur, leguntur; dum recognoscimus, probantur. Idoneum, opinor, testimonium diuinitatis ueritas diuinationis.

90 Guerra (1991: p. 117)

91 Kaufman (1991: p. 172).

92 Irenaeus, Adversus haereses 2.28.2: Scripturae quidem perfectae sunt, quippe a Verbo Dei et Spiritu ejus dictae.

93 Sesboüé (1981: pp. 886-887): “Ainsi donc non seulement la prophétie est une preuve de l'êvénement, mais l'êvénement à son tour devient une preuve de la prophétie: le Verbe incarné est envoyé tel qu'il avait été annoncé."

94 Aune (1983: pp. 126-129). 
In other words, additional extra-scriptural proof that Jesus is the Messiah is a sine qua non for warrant by Scripture. This simply means that any argument based on the fulfilment of prophecies requires a premise in which it is assumed that Jesus is the Messiah. Can this be accomplished? Certainly, but only by using other types of personal epistemic justification, such as warrant by miracles, superior moral behaviour, or spiritual testimony. Robert Grant reached similar conclusions, despite not working with the concept of epistemic justification at all, in his statement that "[t]he underlying axiom which made prophecy credible was the omnipotence of God. No matter how stable the present world might seem, no matter how apparently unbreakable the chain of cause and effect, God would act and nothing could resist his power. Thus the miracle stories at the same time reflect this belief and are used to confirm it. ${ }^{.95}$ Warrant by Scripture (or prophecy fulfilment) therefore requires personal epistemic justification for its conclusions to be valid.

\section{(5) Epistemic justification by tradition}

Our final warrant of the truth of Christian belief may be found in tradition. For most early Christian authors, the power of tradition consisted of an unbroken lineage beginning from God as the ultimate source of knowledge and spreading through reliable channels until their own time. This line of thought was important for the self-definition of early Christian communities as keepers and guardians of the "new covenant" preached by Jesus and his apostles. In the First Letter of Clement, we read that "[t]he apostles received the gospel for us from the Lord Jesus Christ; Jesus the Christ was sent forth from God. [...] So, preaching both in the country and in the towns, they appointed their first fruits, when they had tested them by the Spirit, to be bishops and deacons for the future believers" ${ }^{96}$ Irenaeus added prophets to the equation when he spoke about the "preaching of the Church, which the prophets proclaimed (as I have already demonstrated), but which Christ brought to perfection, and the apostles have handed down", ${ }^{97}$ thus establishing the truth that had been "announced by the prophets, taught by the Lord, delivered by the apostles, kept alive and passed on by the church specifically by means of its presbyterial succession" ${ }^{98}$ A lengthier section from Tertullian is well worth citing

95 Grant (1952: p. 171).

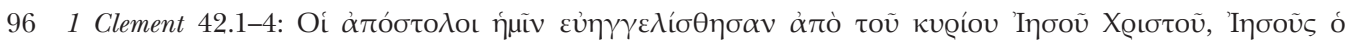

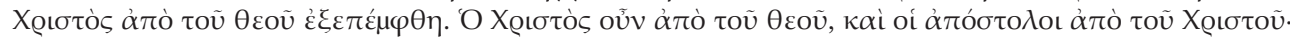

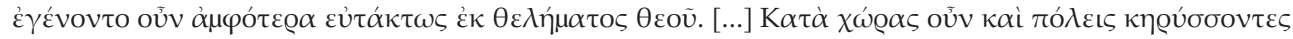

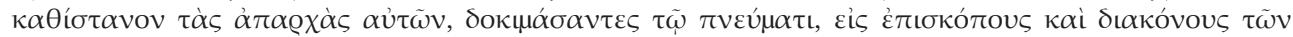

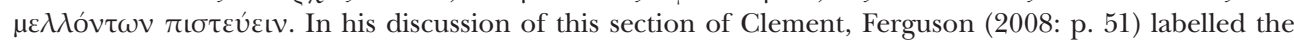
tradition a "divine chain of authority".

97 Irenaeus, Adversus haereses 5, praefatio: [...] et veritate ostensa, et manifestato praeconio Ecclesiae, quod prophetae quidem praeconaverunt, quemadmodum demonstravimus, perfecit autem Christus, Apostoli vero tradiderunt, a quibus Ecclesia accipiens, per universum mundum sola bene custodiens, tradidit filiis suis [...].

Hefner (1964: p. 304). 
in full, since it clearly explains the role of tradition in the context of the other warrants introduced above and brings them together into a coherent, persuasive whole: ${ }^{99}$

\begin{abstract}
"Christ Jesus [...] did, while He lived on earth, Himself declare what He was, what He had been, what the Father's will was which He was administering, what the duty of man was which He was prescribing; (and this declaration He made,) either openly to the people, or privately to His disciples, of whom He had chosen the twelve chief ones to be at His side, and whom He destined to be the teachers of the nations. Accordingly, after one of these had been struck off, He commanded the eleven others, on His departure to the Father, to go and teach all nations, who were to be baptized into the Father, and into the Son, and into the Holy Ghost. [...] they obtained the promised power of the Holy Ghost for the gift of miracles and of utterance; and after first bearing witness to the faith in Jesus Christ throughout Judaea, and founding churches (there), they next went forth into the world and preached the same doctrine of the same faith to the nations. They then in like manner founded churches in every city, from which all the other churches, one after another, derived the tradition of the faith, and the seeds of doctrine, and are every day deriving them, that they may become churches. Indeed, it is on this account only that they will be able to deem themselves apostolic, as being the offspring of apostolic churches." (Transl. P. Holmes).
\end{abstract}

Again, it is not difficult to see why warrant by tradition belongs firmly within the personal mode of epistemic justification, or rather, as was the case with warrant by prophecy fulfilment, requires personal epistemic justification as a sine qua non. Furthermore, this argument does not concern exclusively the Church but could be seen as a recursive extension of warrant by spiritual testimony: The trajectory of truth leads from God to Jesus; Jesus as Christ lends authority to both prophets (by fulfilling prophecies) and apostles (by endowing them with Holy Spirit); and the teachings of both these groups, as written down in parts of the Old and New testaments, are further disseminated by growing Christian communities, eventually coming together into a single Church.

99 Tertullianus, De praescriptione hereticorum 20.1-6: Christus Iesus, Dominus noster, [...] quisquis est, cuiuscumque Dei filius, cuiuscumque materiae homo et Deus, cuiuscumque fidei praeceptor, cuiuscumque mercedis repromissor, quid esset, quid fuisset, quam patris uoluntatem administraret, quid homini agendum determinaret, quamdiu in terris agebat, ipse pronuntiabat siue populo palam, siue discentibus seorsum, ex quibus duodecim praecipuos lateri suo allegerat destinatos nationibus magistros. Itaque uno eorum decusso reliquos undecim digrediens ad patrem post resurrectionem iussit ire et docere nationes tinguendas in Patrem et in Filium et in Spiritum sanctum. Statim igitur apostoli - quos haec appellatio missos interpretatur - adsumpto per sortem duodecimo Matthia in locum Iudae ex auctoritate prophetiae quae est in psalmo Dauid, consecuti promissam uim Spiritus sancti ad uirtutes et eloquium, primo per Iudaeam contestata fide in Iesum Christum et ecclesiis institutis, dehinc in orbem profecti eamdem doctrinam eiusdem fidei nationibus promulgauerunt. Et perinde ecclesias apud unamquamque ciuitatem condiderunt, a quibus traducem fidei et semina doctrinae ceterae exinde ecclesiae mutuatae sunt et cottidie mutuantur ut ecclesiae fiant. Ac per hoc et ipsae apostolicae deputantur ut suboles apostolicarum ecclesiarum. 


\section{(6) Athens and Jerusalem}

Following this sketch of the basic types of personal epistemic justification in early Christian writings, I will show that (1) the endorsement of the personal mode of epistemic justification does not preclude the use of the impersonal mode, but (2) the impersonal mode has limited applicability and, in cases with apparent conflicts between the two modes of epistemic justification, the personal mode takes preference. The relationship between the personal and impersonal modes is thus hierarchical, not mutually exclusive. The attitude of early Christian writers towards the impersonal mode of epistemic justification can be conveniently gauged by their reception of Greek philosophy, because, notwithstanding the variety of Hellenistic philosophical schools, impersonal epistemic justification provides a common foundation for most if not all of them. It is important to emphasize again that none of the early Christian authors reject impersonal epistemic justification a priori. Recent studies established this conclusion with respect to Paul ${ }^{100}$ and it is trivial to show that this thesis also holds for later authors.

Justin Martyr developed an original approach based on the concept of the "spermatic word", which provided rudimentary knowledge even to outsiders: "For each man spoke well in proportion to the share he had of the spermatic word, seeing what was related to it." ${ }^{101}$ Likewise, when Irenaeus discussed the question of whether angels could have been ignorant of the Supreme God, he claimed that the truth of monotheism can be established without an appeal to revelation on purely rational grounds because "although no one knows the Father, except the Son, nor the Son except the Father, and those to whom the Son will reveal Him, yet all [beings] do know this one fact at least, because reason, implanted in their minds, moves them, and reveals to them [the truth] that there is one God, the Lord of all". ${ }^{102}$ Even Tertullian, who, as will be shown below, was not very accommodating of pagan philosophy, claimed that "the great majority of the human race, though ignorant even of Moses' name, not to mention his written works, do for all that know Moses' God" 103 since "[t]he knowledge inherent in the soul since the beginning is God's endowment", ${ }^{104}$ or, as he put it in another treatise with respect to the immortality of the soul, "some things are known even by nature". ${ }^{105}$ However, impersonal epistemic

100 Moores (1995); Scott (2009).

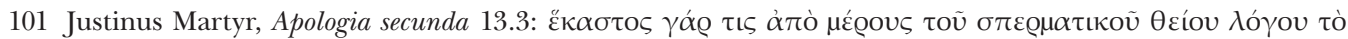

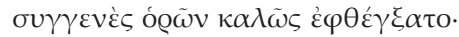

102 Irenaeus, Adversus haereses 2.6.1: Unde etiamsi nemo cognoscit Patrem nisi Filius, neque Filium, nisi Pater, et quibus Filius revelaverit, tamen hoc ipsum omnia cognoscunt, quando ratio mentibus infixa moveat ea et revelet eis, quoniam est unus Deus, omnium Dominus.

103 Tertullianus, Adversus Marcionem 1.10.2: Denique maior popularitas generis humani, ne nominis quidem Moysei compotes, nedum instrumenti, deum Moysei tamen norunt [...].

104 Tertullianus, Adversus Marcionem 1.10.3: Ante anima quam prophetia. Animae enim a primordio conscientia dei dos est $[\ldots]$.

105 Tertullianus, De resurrectione mortuorum 3.1: Est quidem et de communibus sensibus sapere in dei rebus, sed in testimonium ueri, non in adiutorium falsi, quod sit secundum diuinam, non contra diuinam dispositionem. Quaedam enim et naturaliter nota sunt, ut inmortalitas animae penes plures, ut deus noster penes omnes. 
justification of things divine, which eventually came to be known as "natural theology", brings about two major problems.

First, although reason unaided by revelation can, according to early Christian writers, establish some truths (e.g. "God exists", "God is one", "the soul is immortal"), it is hopelessly deficient in establishing other often even more important truths (e.g. "God sent Jesus as the Messiah to redeem humanity for its sins by dying on the cross"). Second, whenever there is an apparent conflict between revealed truth warranted by personal epistemic justification and any other type of knowledge (warranted by impersonal epistemic justification), the revealed truth is always accorded preferential status. Therefore, impersonal epistemic justification in early Christianity was subordinated to personal epistemic justification.

Suppose we establish a "minimal version" of Christianity using the Pauline formula of faith from 1 Corinthians and have it comprise the following propositions: (1) Jesus died on the cross, (2) Jesus was bodily raised from the dead, and (3) his death and resurrection took place in order to redeem humanity. ${ }^{106}$ This "minimal version" is by no means chosen arbitrarily, as Chapter 15 of 1 Corinthians is the section of the Pauline corpus most cited in Christian writings of the second century ${ }^{107}$ and Paul himself makes the importance of these propositions abundantly clear, since "if Christ has not been raised,

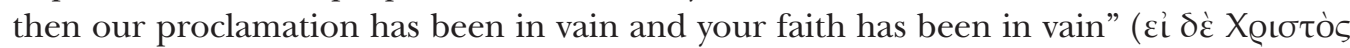

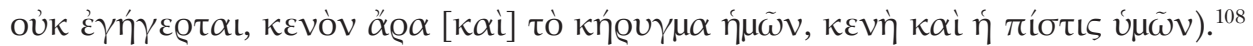

To establish the truth of these propositions, one may use the argumentative strategy of personal epistemic justification, as presented above, but is there any conceivable way to warrant their truth by means of impersonal epistemic justification? The answer is an unqualified "no", ${ }^{109}$ or even worse. Here, the two basic methodological approaches clash and Paul is well aware of this fact. The apostle to the Gentiles famously solves the conflict at the beginning of his letter as follows: $:^{110}$

"For the message about the cross is foolishness ( $\mu \omega$ Qí $\alpha$ ) to those who are perishing, but to us who are being saved it is the power of God. For it is written, 'I will destroy the wisdom of the wise, and the discernment of the discerning I will thwart.' Where is the one who is

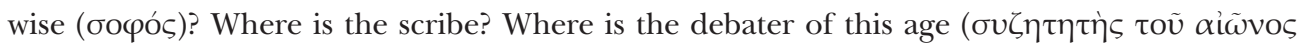

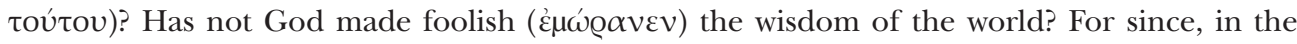
wisdom of God, the world did not know God through wisdom, God decided, through the

1061 Corinthians 15, 3-4.

107 Meunier (2006: p. 332).

1081 Corinthians 15, 14.

109 Any attempts to "rationalize" the resurrection of Jesus are bound to fail. One need only recall Athenagoras' (or pseudo-Athenagoras?) treatise On Resurrection and the unflattering, yet entirely correct, conclusions Grant (1952: p. 242) drew with respect to it: "In this example we see the rationalistic tendency of apologetic leading to its absurd conclusion. Athenagoras is thoroughly unrealistic. It is not as a Christian, however, that he goes astray; it is as an amateur philosopher convinced of the validity of his concept of "nature" and of his deductive method."

1101 Corinthians 1, 18-25. 


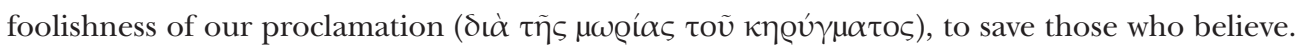

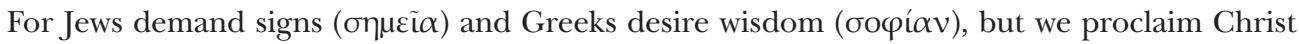

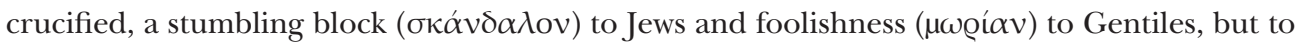
those who are the called, both Jews and Greeks, Christ the power of God and the wisdom of God. For God's foolishness is wiser than human wisdom ( $\dot{\alpha} v \theta \varrho \omega ́ \tau \omega \nu ~ \varepsilon ̇ \sigma \tau i ́ v)$, and God's weakness is stronger than human strength." (Transl. NRSV).

Whenever impersonal epistemic justification stands in the way of revelation, it is simply discarded. Indeed, "Paul leaves not the slightest doubt that God has rejected all that rests on merely human wisdom", ${ }^{111}$ "the cross stands in absolute, uncompromising contradiction to human wisdom", ${ }^{112}$ and "[t]he cross makes hash of all secular and religious attempts based on human wisdom to make sense of God and the world". ${ }^{113}$ However damning these interpretations are of the human faculty of reasoning, almost echoing Luther's critique of "that beautiful whore" Reason, ${ }^{114}$ David Garland was right to add that "[w]e should not jump to the conclusion that Paul denigrates the human faculty of reason or thinks that faith and reason are irreconcilable". ${ }^{115}$ If we focus on the terms introduced in this paper, the personal and impersonal modes of epistemic justification are not irreconcilable in general, but in this particular instance they unfortunately are and "reason" has to make way. Paul's solution, the very first Christian one recorded in writing, served as a blueprint for virtually all early Christian authors, even those who did not shudder at expressing a degree of admiration for Greek philosophy. ${ }^{116}$

Justin readily granted Greek philosophers some access to truth through participation in the "spermatic word" (he even considered all those who lived $\mu \varepsilon \tau \dot{\alpha} \lambda$ hó $0 v$ Christians, including the likes of Socrates and Heraclitus), ${ }^{117}$ yet this access was severely limited.

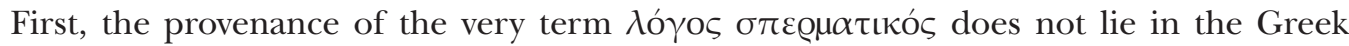
philosophical tradition (often connected with Middle Platonism, while some argue for a Stoic origin), ${ }^{118}$ but in the expression "Word of God" prevalent in the Septuagint. ${ }^{119}$

111 Morris (1985: p. 44).

112 Fee (1987: p. 66).

113 Garland (2003: p. 63).

114 For a short outline of Luther's critique of human reasoning unaided by revelation, see Kaufmann (1958: pp. 305-307).

115 Garland (2003: p. 66).

116 What Scaglioni (1972: p. 213) stated about Tertullian in respect to the relationship between "faith" and "reason" would be valid for virtually all early Christian apologists and theologists, namely that "il discorso di Paolo ha inciso profondamente nell'animo di Tertulliano, così che riuscirebbe difficile intenderne la la posizione su questo punto, prescindendo dall'Apostolo."

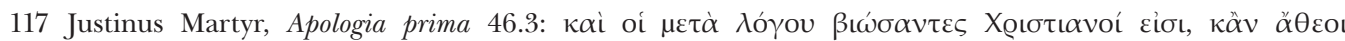

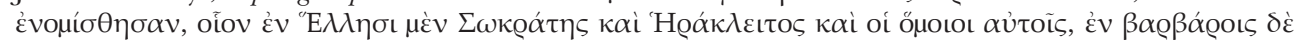

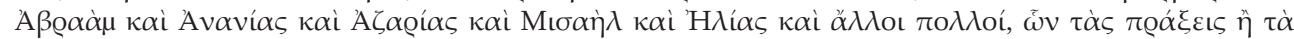

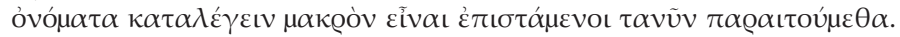

118 Wright (1982: p. 82).

119 Price (1988: p. 20). Piper (1961: pp. 155-156) emphasized the fact that Justin's $\lambda$ ó $\gamma o \varsigma$ is not employed congruently with its previous uses in Greek philosophy: "While it has often been held that Justin borrowed 
More importantly, Justin very openly asserted that revealed Christian doctrine seemed

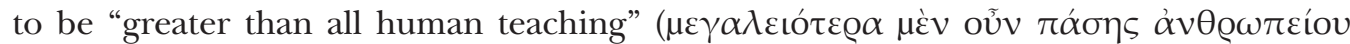

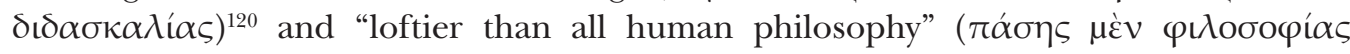

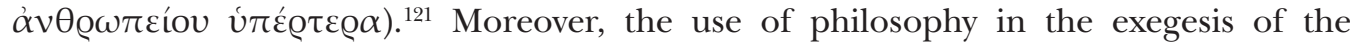
Scripture is more than limited as proper interpretation of Scripture always requires an element of divine grace. ${ }^{122}$ As Winrich Löhr summarized, for Justin "[t]he poets and philosophers had access to divine truth because they read scripture and derived their wisdom from it. But their insight was partial at best; it is only with the incarnation that the fullness of divine truth became accessible." ${ }^{123}$ This "imperialistic view of history", ${ }^{124}$ typical of not only Justin but early Christian discourse in general, considers knowledge gained through impersonal epistemic justification to be subordinate to revelation. It can be hardly denied that "[u]ltimately, Justin establishes a Christological criterion of truth" or that "the controlling factor is the truth as it is in Christ which for Justin constitutes an exclusive and exhaustive touchstone". ${ }^{125}$ The subordination of philosophical method to revelation becomes even clearer when one compares appeals to reason in a Greek philosophical text and to those in a Christian text. Cyrille Crépey, who did just that by juxtaposing Marcus Aurelius' Meditations with Justin's oeuvre, concluded that for the Roman emperor there was no other authority other than reason itself, while for Justin "human wisdom can attain but a part of the truth, not the whole truth that is revealed only by Christ himself, Reason in the flesh". ${ }^{126}$

Unlike Justin, Irenaeus was not overly preoccupied with the opinions of philosophers and this fact alone probably speaks for itself. The bishop of Lyon presented only a single positive evaluation of a Greek philosopher, noting that "Plato is proved to be more religious than these men [sc. Marcion and his followers], for he allowed that the same God was both just and good, having power over all things, and Himself executing judgment,

the concept of the Logos from Philo or from Stoicism, a careful investigation will show that at the best he might have received from those philosophies the stimulus for the use of that term. His understanding of its place in human thought and in metaphysics, however, differs greatly from them."

120 Justinus Martyr, Apologia secunda 10.1-3.

121 Justinus Martyr, Apologia secunda 15.3.

122 This important point is argued for by Pycke (1961), mostly by analysing sections of the Dialogue. He concluded (op. cit., p. 77): "Justin met avant tout l'accent sur la nécessité de la grâce pour comprendre les Écritures; des raisonnements habiles n'y suffisent pas. L'intelligence des Écritures suppose nécessairement une intervention de Dieu ou du Christ, sans laquelle la doctrine des Écritures pourrait paraître au lecteur absurde et indigne de Dieu."

123 Löhr (2000: p. 407). A similar conclusion with respect to Justin's view of philosophy was reached by De Vogel (1978: p. 381): "Platonism had only a partial view of the truth and was mixed with error; Christianity was Truth in its fullness. Its relation to philosophy was that of completion and correction."

124 Droge (1987: p. 315): "Together, both the logos theory and the theory of dependence serve to reinforce Justin's imperialistic view of history: Christianity is responsible for whatever truths exist in Greek philosophy. More importantly, Christianity is the sole bearer of truth in its entirety."

125 Wright (1982: pp. 81, 83).

126 Crépey (2009: p. 75): “[L]a sagesse humaine ne puisse atteindre qu’une partie de la vérité, non la vérité intégrale que seul le Christ, Raison incarnée, est à même de révéler." 
expressing himself thus"127 - however, as William Schoedel remarked, "one is left wondering whether a somewhat grudging comparison of Plato with Marcion speaks highly of the former". ${ }^{128}$ More to the point, in another section of his work, Irenaeus even constructed an interesting argument in favour of the irreducibility of revelation to "natural theology": ${ }^{129}$

"But I will merely say, in opposition to these men [sc. philosophers] - Did all those who have been mentioned, with whom you have been proved to coincide in expression, know, or not know, the truth? If they knew it, then the descent of the Saviour into this world was superfluous. For why [in that case] did He descend? Was it that He might bring that truth which was [already] known to the knowledge of those who knew it?" (Transl. A. Roberts \& W. Rambaut).

The relationship between "faith" and human capacity of unaided ratiocination in the writings of Clement of Alexandria is extremely complicated and a detailed analysis would require much more space than may be allotted to this problem here. His notions of "truth" and especially "faith" are highly polysemic ${ }^{130}$ and his free, syncretic use of various epistemological systems does not aid clarity, ${ }^{131}$ yet I find it uncontroversial to conclude that for Clement, just as for Justin and Irenaeues, the impersonal mode of epistemic justification is subordinated to the personal mode and the highest authority is accorded to the Scripture, which is "not a mere book that has authority in the religious community" but "the voice of God". ${ }^{132}$ His concept of the "perfect gnosis" described in the Stromata is only a superstructure for well-educated Christians and, as has been noted

127 Irenaeus, Adversus haereses 3.25.5: Quibus religiosior Plato ostenditur, qui eundem Deum et justum et bonum confessus est, habentem potestatem omnium [...].

128 Schoedel (1959: p. 24).

129 Irenaeus, Adversus haereses 2.14.7: Dicemus autem adversus eos: utrumne hi omnes qui praedicti sunt, cum quibus eadem dicentes arguimini, cognoverunt veritatem, aut non cognoverunt? Et si quidem cognoverunt, superflua est Salvatoris in hunc mundum descensio. Ut quid enim descendebat? An nunquid ut eam quae cognoscebatur veritas, in agnitionem adduceret his, qui cognoscunt eam hominibus?

130 For an analysis of the notion of "truth" in Clement, see Klibengajtis (2004). With respect to the notion of "faith", Osborn (1994: pp. 3-4) differentiated no less than eight different meanings: (1) "preconception"; (2) "assent and decision"; (3) "hearing and seeing"; (4) "listening to God in the scriptures"; (5) "first principle"; (6) "criterion which judges that something was true or false"; (7) "always on the move, from faith to faith, moving up the ladder of dialectic"; and (8) "source of power and stability". A slightly less detailed analysis was offered by Peršić (2005: pp. 157-161), who differentiated three main semantic fields: (1) "attitude of certainty of human spirit in the first, unproved principles from which a proof is derived"; (2) "firm conviction of reason in what is scientifically proven"; and (3) "taking of what is said in the Bible for true without investigation”, while noting that Clement himself criticized field 3. On Clement's concept of $\dot{\alpha} \pi \delta_{\delta} \varepsilon \xi \xi \xi \varsigma$, see especially Havrda (2012), highlighting the ambiguity of Clement's epistemology and noting that "[d]espite conceding that faith cannot be proved in terms of Greek logic, and even chastising his opponents for making such a demand, Clement nevertheless attempts to show that the standpoint of faith is logically sound, and even that it has the force of a scientific demonstration" (op. cit., p. 265).

131 Wolfson (1942: pp. 223-230) saw in Clement's notion of "faith" a combination of Aristotelian and Stoic influences. Lössl (2002: p. 337), however, argued that the influence of Plato and Aristotle was much stronger than was that of the Stoicism of Clement's day.

132 Zuiddam (2010: p. 310 et passim). 
previously, the difference between an illiterate Christian of the Faith and a well-educated Christian of the Gnosis is one of degree, not of kind (unlike the difference between Christians and pagans, which is, of course, qualitative). ${ }^{133}$ By all standards, philosophy is a secondary occupation, mere "propedeutics that has to be overcome"134 and - as Clement never tires of pointing out - everything worthwhile in Greek philosophical writings is stolen from ancient Jewish wisdom anyway. ${ }^{135}$

As seen above, Tertullian allowed that some knowledge obtained by impersonal epistemic justification may be valid (this much is largely agreed upon), ${ }^{136}$ yet this allowance abruptly ends the moment "reason" starts objecting to revealed truth warranted by impersonal epistemic justification. When people say that Jesus was not raised because "what is dead is dead", Tertullian stated that he "shall remember that the heart of the multitude is reckoned by God as ashes, and that the very wisdom of the world is declared foolishness". ${ }^{137}$ Elsewhere, he noted that if philosophers happen to be right, it is only by "some happy chance" (prospero errore) or "through blind luck alone" (caeca felicitate). ${ }^{138}$ If impersonal epistemic justification fails to vindicate itself in the face of the power of baptism to save ${ }^{139}$ or the resurrection of Christ, so much the worse for impersonal epistemic justification: "The Son of God was crucified: I am not ashamed - because it is shameful. The Son of God died: it is immediately credible - because it is silly. He was buried, and rose again: it is certain - because it is impossible." 140

133 Dal Covolo (1998: p. 243): "Clemente divide i cristiani in due classi: i «semplici» e gli «gnostici». Non si tratta di una differenza essenziale, ma solo di grado: i primi sono i credenti che vivono la fede in modo comune, gli altri quelli che conducono una vita di perfezione spirituale."

134 Le Boulluec (1999: p. 188): "La «philosophie» des Grecs est certes utile, mais elle doit être dépassée, elle n'est qu'une propédeutique." The same conclusion was reached by Rizzerio (1998: p. 177): “[...] il est évident que le Principe suprême, Dieu, ne pourra jamais être connu uniquement par l'activité de la raison pure. Car le Dieu des chrétiens est plus qu'un simple Principe, il est une "personne" à aimer, l'objet premier de notre liberté."

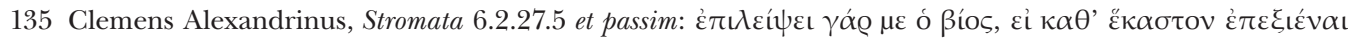

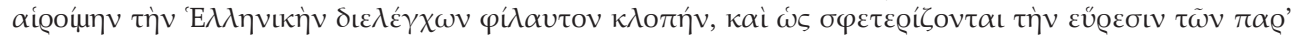

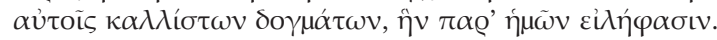

136 Barcala (1976b: p. 245); Hager (1978: pp. 78-79).

137 Tertullianus, De resurrectione carnis 3.3: At cum aiunt: 'Mortuum quod mortuum' et 'Viue dum uiuis' et 'Post mortem omnia finiuntur, etiam ipsa', tunc meminero et cor uulgi cinerem a deo deputatum et ipsam sapientiam saeculi stultitiam pronuntiatam [...].

138 Tertullianus, De anima 2: Plane non negabimus aliquando philosophos iuxta nostra sensisse; testimonium est etiam ueritatis euentus ipsius. Nonnumquam et in procella confusis uestigiis caeli et freti aliqui portus offenditur prospero errore, nonnumquam et in tenebris aditus quidam et exitus deprehenduntur caeca felicitate, sed et natura pleraque suggerentur quasi de publico sensu, quo animam deus dotare dignatus est.

139 Tertullianus, De baptismo 2.2: Quid ergo? Nonne mirandum est lauacro dilui mortem? Si, quia mirandum est, idcirco non creditur, atquin eo magis credendum est: qualia enim decet esse opera diuina nisi super omnem admirationem? Nos quoque ipsi miramur, sed [quia] credimus. Ceterum incredulitas miratur quia non credit: miratur enim simplicia quasi uana, magnifica quasi inpossibilia. For Stockmeier (1972: p. 243), „,[o]hne Zweifel wird hier im Gegenüber von mirari und credere das Paradox christlichen Glaubens sichtbar [...].“

140 Tertullianus, De carne Christi 5.4: Crucifixus est dei filius; non pudet, quia pudendum est. Et mortuus est dei filius; credibile est, quia ineptum est. Et sepultus resurrexit; certum est, quia impossibile. 
While there is a standing tradition of scholarship that understands these sections as merely topical and influenced by Aristotelian rhetoric, ${ }^{141}$ this argument remains unconvincing. In what has been aptly called a "dialectic of the opposites", ${ }^{142}$ Tertullian asked: "What indeed has Athens to do with Jerusalem? What concord is there between the Academy and the Church? What between heretics and Christians?" 143 He continued: "So, then, where is there any likeness between the Christian and the philosopher? Between the disciple of Greece and of heaven? Between the man whose object is fame, and whose object is life? Between the talker and the doer? Between the man who builds up and the man who pulls down? Between the friend and the foe of error? Between one who corrupts the truth, and one who restores and teaches it? Between its chief and its custodier?". ${ }^{14}$ The very linguistic and stylistic features of these sections mirror those segments of the New Testament in which two irreconcilable opposites are compared. ${ }^{145}$

The powerful rhetoric of these lines led some scholars to view Tertullian as a champion of "faith" against "reason", ${ }^{146}$ yet this interpretation does not seem to do justice to someone hailed by modern scholarship as "first theologian of the West" (in the very title of a book, no less). ${ }^{147}$ Rather, as Justo González noted, ${ }^{148}$ Tertullian "is saying that the criterion of natural reason, usually valid, is not always ultimately valid, for that reason itself shows that God, who is the ultimate deciding factor, does not have to subject himself to it. He is also saying that in such cases the criterion of truth is not some inner logic which one can discover by purely rational investigation, but rather whether God did or did not will the event in question - in this case the incarnation and its sequel - to happen". In other words, the procedure of impersonal epistemic justification is valid if and only if it does not threaten revealed wisdom established by means of personal epistemic justification. The use of impersonal epistemic justification is thus limited in scope and also subordinated to personal epistemic justification in respect to value.

The established primacy of personal epistemic justification is then vital in defence of what Irenaeus calls "the rule of truth" (regula veritatis) ${ }^{149}$ and Tertullian the "rule of

141 Bauer (1970: pp. 11-12); Peršić (2005: p. 156); Bochet (2008: pp. 267-271).

142 Barcala (1976a: p. 357): "Esta forma de reflexión es la que designamos con el nombre de «dialéctica de los contrarios»."

143 Tertullianus, De praescriptione haereticorum 7.9: Quid ergo Athenis et Hierosolymis? quid academiae et ecclesiae? quid haereticis et christianis?

144 Tertullianus, Apologeticum 46.18: Adeo quid simile philosophus et Christianus, Graeciae discipulus et caeli, famae negotiator et salutis uitae, uerborum et factorum operator, et rerum aedificator et destructor, et interpolator et integrator ueritatis, furator eius et custos?

145 Stanton (1973: p. 90); in addition to his examples, see also 2 Corinthians 6, 14-16.

146 Labhardt (1950: passim).

147 Osborn (1997).

148 González (1974: p. 21). See also Lortz (1987: p. 132): "Die Wahrheit par excellence liegt aber im Glauben. Wer diesen gesucht und gefunden hat und sich zu eigen gemacht hat, der darf wohl zur Stärkung und Befestigung eben dieses Glaubens noch weiter forschen, aber nicht so, daß dieser Glaube selbst wieder in Frage gestellt würde."

149 Irenaeus, Adversus haereses 1.22.1. 
faith" (regula fidei). ${ }^{150}$ While there have been attempts to connect the development of this concept with anti-heretical polemics, ${ }^{151} \mathrm{I}$ am rather inclined to accept the views of Bengt Hägglund, for whom the rule is emphatically not a "summary of the doctrine invented or formulated in the fight against heresies", but "faith itself, the truth itself". ${ }^{152}$ Its role is to preserve the purity of Christian faith and defend it against any intrusions by the impersonal mode of epistemic justification (and heterodox interpretations thereof) - indeed, "when the biblical message seems to go against reason, the rule of faith has something to say about it". ${ }^{153}$ In confrontation with Christianity, Greek philosophical tradition, and thereby impersonal epistemic justification, played an initially important but clearly subservient role which only withered and waned as the centuries went on. ${ }^{154}$ As André Beckaert once wrote, "philosophy did not absorb Christianity but was absorbed by it" 155

In conclusion, despite the necessarily concise and fragmentary sketch offered by this paper, it is hoped that the central distinction between the personal and impersonal modes of epistemic justification introduced herein may serve as a small step in the direction of replacing the traditional labels of "faith" versus "reason" or "religion" versus "philosophy" in analyses of the arguments put forward by the earliest Christian authors in the first three centuries CE.

\section{Bibliography}

\section{Primary sources and translations}

ANF: Ante-Nicene Fathers. (1867-1873). Ed. A. Roberts, \& J. Donaldson. Edinburgh: T\&T Clark. Aristide di Atene, Apologia. (1988). Ed. C. Alpigiano. Firenze: Nardini Editore.

Aristotle, Metaphysics. (1924). Ed. W. D. Ross. Oxford: Clarendon Press.

Athenagoras, Legatio E De resurrectione. (1972). Ed. W. R. Schoedel. Oxford: Clarendon Press.

150 Tertullianus, De praescriptione haereticorum 13.1.

151 This view was expressed by Farmer (1984) and Ferguson (2001), amongst others.

152 Hägglund (1958: p. 4): "Nicht eine im Kampfe gegen die Häresien erfundene oder formulierte Lehrzusammenfassung wird damit gemeint, sondern der Glaube selbst, die Wahrheit selbst, die in der heiligen Schrift, in der Verkündigung des Herrn und der Apostel, geoffenbart und bekanntgemacht worden ist, und in der Taufe einem jeden Christen übergeben und anvertraut wird."

153 Fernández (2004: p. 120): "Cuando el mensaje bíblico parece ir contra razón, la regla de fe tiene una palabra que decir."

154 Although he focused on Late Antiquity and the Early Middle Ages, Freeman (2005) gave a good account of this process and his conclusion bears a close resemblance to the argument of the present paper (op. cit., p. 335): "It has never been part of the argument of this book that Christians did not attempt to use rational means of discovering theological truths. The problem was rather that reason is only of limited use in finding such truths."

155 Beckaert (1961: p. 62): "L'évolution historique manifeste bien que la philosophie n'a pas absorbée le christianisme, mais qu'elle s'est résorbée en lui." See also Grant (1952: p. 263): "As regards these basic physical and metaphysical questions, Nestle rightly observes that Christianity was in no way whatever the heir of Greek philosophy." 
Cicero, De natura deorum. (1933). Ed. W. Ax. Leipzig: Teubner.

Clemens Alexandrinus, Le protreptique. (1949). Ed. C. Mondésert. Paris: Éditions du Cerf.

Clemens Alexandrinus, Stromata. (1960-1970). Ed. L. Früchtel, O. Stählin, \& U. Treu. In Iidem (Eds.), Clemens Alexandrinus (Band 2, 3). Berlin: Akademie Verlag.

Diogenes Laertius, Vitae Philosophorum. (1999). Ed. M. Marcovich. Leipzig: Teubner.

DK: Die Fragmente der Vorsokratiker (2004-2005). Ed. H. Diels, \& W. Kranz. Zürich: Weidmann.

Hechos apócrifos de los Apóstoles, I: Hechos de Andrés, Juan y Pedro. (2004). Ed. A. Piñero, \& G. Del Cerro. Madrid: Biblioteca de Autores Cristianos.

Hechos apócrifos de los Apóstoles II: Hechos de Pablo y Tomás. (2005). Ed. A. Piñero, \& G. Del Cerro. Madrid: Biblioteca de Autores Cristianos.

Homerus, Ilias (1998-2000). Ed. M. L. West. Stuttgart-Leipzig-München: Teubner - K. G. Saur. Irenaeus, Epideixis Ẽ Adversus haereses I-V (1993-2001). Ed. N. Brox. Freiburg-Basel: Herder.

Justinus Martyr, Apologiae pro Christianis. (1994). Ed. M. Marcovich. Berlin-New York: Walter de Gruyter.

Justinus Martyr, Dialogus cum Tryphone. (1997). Ed. M. Marcovich. Berlin-New York: Walter de Gruyter.

Los evangelios apócrifos. (2006). Ed. A. De Santos Otero. Madrid: Biblioteca de Autores Christianos. Origen, Contra Celsum. (1965). Transl. H. Chadwick. Cambridge: Cambridge University Press.

Origenes, Contre Celse. (1967-1969). Ed. M. Borret. Paris: Éditions du Cerf.

Novum Testamentum Graecae. (1993). Ed. E. Nestle, B. Aland, K. Aland, \& al. Stuttgart: Deutsche Bibelgesellschaft.

NRSV: New Oxford Annotated Bible: New Revised Standard Version. (2010). Ed. M. D. Coogan. Oxford: Oxford University Press.

New Testament Apocrypha, I: Gospels and Related Writings. (2003). Ed. W. Schneemelcher, \& R. McL. Wilson. Louisville-London: Westminster John Knox Press.

New Testament Apocrypha, II: Writings Relating to the Apostles, Apocalypses and Related Subjects. (2003). Ed. W. Schneemelcher, \& R. McL. Wilson. Louisville-London: Westminster John Knox Press.

Tatianus, Oratio ad Graecos and Fragments. (1982). Ed. M. Whittaker. Oxford: Clarendon Press. Tertullianus, Opera Catholica. Adversus Marcionem. (1954). Ed. E. Dekkers, \& al. Turnhout: Brepols. Tertullianus, Opera Montanistica. (1954). Ed. A. Gerlo, \& al. Turnhout: Brepols.

The Acts of the Christian Martyrs. (1972). Ed. H. Musurillo. Oxford: Clarendon Press.

The Apostolic Fathers: Greek Texts and English Translations. (2007). Ed. M. W. Holmes. Grand Rapids: Baker Academic.

Theophilus Antiochenus, Ad Autolycum. (1970). Ed. R. M. Grant. Oxford: Clarendon Press.

\section{Secondary sources}

Aune, D. E. (1983). Prophecy in Early Christianity and the Ancient Mediterranean World. Grand Rapids: Eerdmans.

Barcala, A. (1976a). «Con más razón hay que creer ...» (Un pasaje olvidado de Tertuliano). Estudios Eclesiásticos, 51(198), 347-367. 
Barcala, A. (1976b). El antifilosofismo de Tertuliano y la fe como reconocimiento. Revista Española de Teología, 36(1-2), 233-250.

Barnes, J. (1997). Raison et foi: Critique païenne et réponses chrétiennes. Annuaire de la Société Suisse de Philosophie (Studia Philosophica), 56, 183-209.

Bauer, J. B. (1970). Credo, quia absurdum (Tertullian, De carne Christi 5). In V. Flieder (Ed.), Festschrift Franz Loidl zum 65. Geburtstag (Vol. 1; pp. 9-12). Wien: Hollinek.

Beckaert, A. (1961). L'évolution de l'intellectualisme grec vers la pensée religieuse et la relève de la philosophie par la pensée chrétienne. Revue des Études Byzantines, 19, 44-62.

Bochet, I. (2008). Transcendance divine et paradoxe de la foi chrétienne: La polémique de Tertullien contre Marcion. Recherches de Science Religieuse, 96(2), 255-274.

Braun, R. (1971). Tertullien et la philosophie païenne: Essai de mise au point. Bulletin de l'Association Guillaume Budé, 1(2), 231-251.

Bremmer, J. N. (2002). Magic in the Apocryphal Acts of the Apostles. In J. N. Bremmer, \& J. R. Veenstra (Eds.), The Metamorphosis of Magic from Late Antiquity to the Early Modern Period (pp. 51-70). Leuven-Paris: Peeters.

Chadwick, H. (1993). The Gospel a Republication of Natural Religion in Justin Martyr. Illinois Classical Studies, 18, 237-247.

Crépey, C. (2009). Marc Aurèle et Justin Martyr: Deux discours sur la raison. Revue d'Histoire et de Philosophie Religieuses, 89(1), 51-77.

Dal Covolo, E. (1998). Conoscenza «razionale» di Dio, contemplazione ed esperienza «mistica»: Ignazio di Antiochia, Clemente e Origene. In L. Padovese (Ed.), Atti del V Simposio di Tarso su S. Paolo Apostolo (pp. 237-251). Roma: Istituto Francescano di Spiritualità \& Pontificio Ateneo Antoniano.

Dassmann, E. (2009). San Pablo en la primera teología cristiana hasta Ireneo. Anuario de Historia de la Iglesia, 18, 239-257.

De Vogel, C. J. (1978). Problems Concerning Justin Martyr: Did Justin Find a Certain Continuity between Greek Philosophy and Christian Faith? Mnemosyne, 31(4), 360-388.

Droge, A. J. (1987). Justin Martyr and the Restoration of Philosophy. Church History, 56(3), 303-319.

Ehrman, B. D. (2009). Jesus, Interrupted: Revealing the Hidden Contradictions in the Bible. New York: HarperOne.

Ehrman, B. D. (2012). The New Testament: A Historical Introduction to the Early Christian Writings. New York-Oxford: Oxford University Press.

Farkasfalvy, D. (1968). Theology of Scripture in St. Irenaeus. Revue Bénédictine, 78, 319-333.

Farmer, W. R. (1984). Galatians and the Second-century Development of the regula fidei. The Second Century: A Journal of Early Christian Studies, 4(3), 143-170.

Fee, G. D. (1987). The New International Commentary on the New Testament: The First Epistle to the Corinthians. Grand Rapids: Eerdmans.

Félix, V. L. (2014). Las filosofías en la teología de Justino Mártir. Teología y Vida, 55(3), 435-448.

Ferguson, E. (2008). The Appeal to Apostolic Authority in the Early Centuries. Restoration Quarterly, 50(1), 49-62.

Ferguson, T. C. K. (2001). The Rule of Truth and Irenaean Rhetoric in Book 1 of "Against heresies". Vigiliae Christianae, 55(4), 356-375.

Fernández, P. S. (2004). Regulae fidei et rationis: Tradición, razón y Escritura en los primeros siglos. Teología y Vida, 45, 103-121. 
Freeman, C. (2005). The Closing of the Western Mind: The Rise of Faith and the Fall of Reason. New York: Vintage.

Freeman, C. (2009). A New History of Early Christianity. New Haven-London: Yale University Press.

Frend, W. H. C. (2008). Martyrdom and Persecution in the Early Church: A Study of a Conflict from the Maccabees to Donatus (corrected edition of the 1965 original). Cambridge: James Clarke \& Co.

Fumerton, R. (2002). Theories of justification. In P. K. Moser (Ed.), The Oxford Handbook of Epistemology (pp. 204-233). Oxford-New York: Oxford University Press.

Garland, D. E. (2003). Baker Exegetical Commentary on the New Testament: 1 Corinthians. Grand Rapids: Baker Academic.

González, J. L. (1974). Athens and Jerusalem Revisited: Reason and Authority in Tertullian. Church History, 43(1), 17-25.

Granger, H. (2007). Prose and Poetry: Xenophanes of Colophon. Transactions and Proceedings of the American Philological Association, 137(2), 403-433.

Grant, R. M. (1952). Miracle E Natural Law in Graeco-Roman and Early Christian Thought. Amsterdam: North-Holland Publishing Co.

Guerra, A. J. (1991). Polemical Christianity: Tertullian's Search for Certitude. The Second Century: A Journal of Early Christian Studies, 8, 109-123.

Guthrie, W. K. C. (1962). A History of Greek Philosophy, I: The Earlier Presocratics and the Pythagoreans. Cambridge: Cambridge University Press.

Hager, F.-P. (1978). Zur Bedeutung der griechischen Philosophie für die christliche Wahrheit und Bildung bei Tertullian und bei Augustin. Antike und Abendland, 24, 76-84.

Hägglund, B. (1958). Die Bedeutung der »regula fidei« als Grundlage theologischer Aussagen. Studia Theologica, 12(1), 1-44.

Hauck, R. J. (1988). "They Saw What They Said They Saw”: Sense Knowledge in Early Christian Polemic. The Harvard Theological Review, 81(3), 239-249.

Havrda, M. (2012). Demonstrative Method in Stromateis VII: Context, Principles, and Purpose. In M. Havrda, V. Hušek, J. Plátová (Eds.), The Seventh Book of the Stromateis: Proceedings of the Colloquium on Clement of Alexandria (Olomouc, October 21-23, 2010) (pp. 261-275). Leiden-Boston: Brill.

Hefner, P. (1964). Theoretical Methodology and St. Irenaeus. The Journal of Religion, 44(4), 294-309. Helm, P. (Ed.). (1999). Faith Eॄ Reason. Oxford: Oxford University Press.

Jossa, G. (2003). La valutazione Cristiana dei Greci da Giustino a Ippolito. In P. Defosse (Ed.), Hommage à Carl Deroux, V: Christianisme et Moyen Âge, Néo-latin et survivance de la latinité (pp. 170-179). Brussels: Latomus.

Kaufman, P. I. (1991). Tertullian on Heresy, History, and the Reappropriation of Revelation. Church History, 60(2), 167-179.

Kaufmann, W. (1958). Critique of Religion and Philosophy. Princeton: Princeton University Press.

Kee, H. C. (1986). Medicine, Miracle and Magic in New Testament Times. Cambridge: Cambridge University Press.

Kelhoffer, J. A. (1999). Ordinary Christians as Miracle Workers in the New Testament and the Second and Third Century Christian Apologists. Biblical Research: Journal of the Chicago Society of Biblical Research, 44, 23-34. 
Kelhoffer, J. A. (2001). The Apostle Paul and Justin Martyr on the Miraculous: A Comparison of Appeals to Authority. Greek, Roman, and Byzantine Studies, 42, 163-184.

Klibengajtis, T. (2004). Die Wahrheitsbezeichnungen des Clemens von Alexandrien in ihrem philosophischen und theologischen Kontext. Vigiliae Christianae, 58(3), 316-331.

Kollmann, B. (1996). Jesus und die Christen als Wundertäter: Studien zu Magie, Medizin und Schamanismus in Antike und Christentum. Göttingen: Vandenhoeck \& Ruprecht.

Kollmann, B. (2011). Neutestamentliche Wundergeschichten. Stuttgart: Kohlhammer.

Kühneweg, U. (1988). Die griechischen Apologeten und die Ethik. Vigiliae Christianae, 42(2), 112-120.

Labhardt, A. (1950). Tertullien et la philosophie ou la recherche d'une «position pure». Museum Helveticum, 7(3), 159-180.

Larmer, R. A. (2011). The Meanings of Miracle. In G. H. Twelftree (Ed.), The Cambridge Companion to Miracles (pp. 36-53). Cambridge: Cambridge University Press.

Le Boulluec, A. (1999). Le rencontre de l'hellénisme et de la «philosophie barbare» selon Clément d'Alexandrie. In J. Leclant (Ed.), Cahiers de la Villa «Kérylos» $N^{\circ}$ 9: «Alexandrie, une mégalopole cosmopolite» (pp. 175-188). Paris: Académie des Inscriptions et Belles-Lettres.

Löhr, W. (2000). The Theft of the Greeks: Christian Self-definition in the Age of Schools. Revue d'Histoire Ecclésiastique, 95(3), 403-426.

Lortz, J., \& Manns, P. (Ed.). (1987). Erneuerung und Einheit: Aufsätze zur Theologie- und Kirchengeschichte aus Anlass seines 100. Geburtstages. Stuttgart: Steiner Verlag.

Lössl, J. (2002). Der Glaubenbegriff des Klemens von Alexandrien im Kontext der hellenistischen Philosophie. Theologie und Philosophie, 77(3), 321-337.

Meunier, B. (2006). Paul et les Pères grecs. Recherches de Science Religieuse, 93(3), 331-355.

Moores, J. D. (1995). Wrestling with Rationality in Paul: Romans 1-8 in a New Perspective. Cambridge: Cambridge University Press.

Morgan-Wynne, J. E. (1984). The Holy Spirit and Christian Experience in Justin Martyr. Vigiliae Christianae, 38(2), 172-177.

Morris, L. (1985). The Tyndale New Testament Commentaries: 1 Corinthians. Grand Rapids: Eerdmans.

Moss, C. R. (2010). The Other Christs: Imitating Jesus in Ancient Christian Ideologies of Martyrdom. Oxford: Oxford University Press.

Moss, C. R. (2012). Ancient Christian Martyrdom: Diverse Practices, Theologies, and Traditions. New Haven-London: Yale University Press.

Moss, C. R. (2013). The Myth of Persecution: How Early Christians Invented a Story of Martyrdom. New York: HarperOne.

Munier, C. (1988). La méthode apologétique de Justin le Martyr. Revue des Sciences Religieuses, 62(2), 90-100.

Nietzsche, F. (2005). The Anti-Christ, Ecce Homo, Twilight of the Idols and Other Writings. Cambridge: Cambridge University Press.

Osborn, E. (1994). Arguments for Faith in Clement of Alexandria. Vigiliae Christianae, 48(1), 1-24.

Osborn, E. (1997). Tertullian: First Theologian of the West. Cambridge: Cambridge University Press.

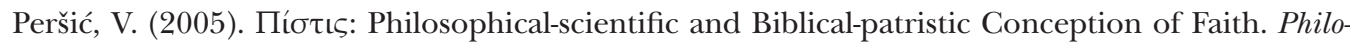
theos, 5, 154-164.

Piper, O. A. (1961). The Nature of the Gospel According to Justin Martyr. Journal of Religion, 41(3), $155-168$. 
Price, R. M. (1988). "Hellenization” and Logos doctrine in Justin Martyr. Vigiliae Christianae, 42(1), 18-23.

Pycke, N. (1961). Connaissance rationnelle et connaisance de grâce chez saint Justin. Ephemerides theologicae Lovanienses, 37, 52-85.

Rizzerio, L. (1998). L'accès à la transcendance divine selon Clément d'Alexandrie: dialectique platonicienne ou expérience de l'“union chrétienne”? Revue des Études Augustiniennes, 44, 159-179.

Scaglioni, C. (1972). «Sapientia mundi» e «Dei sapientia»: L'esegesi di I Cor. 1,18 - 2,5 in Tertulliano. Aevum, 46(3-4), 183-215.

Schoedel, W. R. (1959). Philosophy and rhetoric in the Adversus haereses of Irenaeus. Vigiliae Christianae, 13(1), 22-32.

Scott, I. W. (2009). Paul's Way of Knowing: Story, Experience, and the Spirit. Grand Rapids: Baker Academic.

Sesboüé, B. (1981). La preuve par les Ecritures chez saint Irénée: À propos d'un texte difficile du livre III de l'Adversus haereses. Nouvelle Revue Théologique, 103(6), 872-887.

Sider, R. D. (1980). Credo quia absurdum? Classical World, 73(7), 417-419.

Skarsaune, O. (1987). The Proof from Prophecy: A Study in Justin Martyr's Proof-text Tradition. Leiden: Brill.

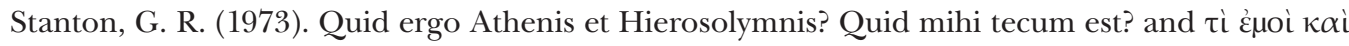
ooí; Rheinisches Museum für Philologie, 116(1), 84-90.

Stockmeier, P. (1972). Zum Verhältnis von Glaube und Religion bei Tertullian. In F. L. Cross (Ed.), Studia patristica XI: Papers Presented to the 5. International Conference on Patristic Studies Held in Oxford 1967 (pp. 242-246). Berlin: Akademie-Verlag.

Swineburne, R. (2001). Epistemic Justification. Oxford: Clarendon Press.

Van der Loos, H. (1965). The Miracles of Jesus. Leiden: Brill.

Van Winden, J. C. M. (1977). Le portrait de la philosophie grecque dans Justin, "Dialogue" I 4-5. Vigiliae Christianae, 31(3), 181-190.

Wolfson, H. A. (1942). The Double Faith Theory in Clement, Saadia, Averroes and St. Thomas, and Its Origin in Aristotle and the Stoics. The Jewish Quarterly Review, New Series, 33(2), 213-264.

Wright, D. F. (1982). Christian Faith in the Greek World: Justin Martyr's Testimony. The Evangelical Quarterly, 54(2), 77-87.

Zimmermann, R. (Ed.). (2013). Kompendium der frühchristlichen Wundererzählungen, 1: Die Wunder Jesu. Gütersloh: Gütersloher Verlagshaus.

Zuiddam, B. A. (2010). Early Orthodoxy: The Scriptures in Clement of Alexandria. Acta Patristica et Byzantina, 21(2), 307-319.

Mgr. Juraj Franek, Ph.D. / j.franek@mail.muni.cz

Department of Classical Studies

Masaryk University, Faculty of Arts

Arna Nováka 1, 60200 Brno, Czech Republic 